\title{
Tax Competition and Income Sorting: Evidence from the Zurich Metropolitan Area
}

\author{
Christoph A. Schaltegger \\ Frank Somogyi \\ Jan-Egbert Sturm
}

CESIFO WORKING PAPER No. 2824

CATEGORY 1: PUBlic FinANCE

OCTOBER 2009

\footnotetext{
An electronic version of the paper may be downloaded

- from the SSRN website:

- from the RePEc website:

- from the CESifo website:

www.SSRN.com

www.RePEc.org

www.CESifo-group.org/wp
} 


\title{
Tax Competition and Income Sorting: Evidence from the Zurich Metropolitan Area
}

\begin{abstract}
In this paper, we provide empirical evidence for the influence of income taxes on the choice of residence of taxpayers at the local level. The fact that Swiss communities can individually set tax multipliers thereby shifting the progressive tax scheme which is fixed at the cantonal (state) level enables us to study the effect of differences in income taxation on individuals' choice of location within an economically and culturally homogeneous region. Using panel IV regressions covering the years 1991-2003 and 171 communities in the Swiss canton of Zurich and spatial error regressions for the 171 communities in 2003, we find substantial evidence for income sorting.
\end{abstract}

JEL Code: H71, H73, R50.

Keywords: tax competition, fiscal federalism, income segregation, income tax.

\author{
Christoph Schaltegger \\ University of St. Gallen \\ Switzerland - St. Gallen \\ christoph.schaltegger@unisg.ch
}

\author{
Frank Somogyi \\ KOF Swiss Economic Institute \\ ETH Zurich \\ Weinbergstrasse 35 \\ Switzerland - 8092 Zurich \\ somogyi@kof.ethz.ch
}

\author{
Jan-Egbert Sturm \\ KOF Swiss Economic Institute \\ ETH Zurich \\ Weinbergstrasse 35 \\ Switzerland -8092 Zurich \\ sturm@kof.ethz.ch
}

We thank the participants of the 2009 EEA Annual Congress in Barcelona, the 2008 Annual Congress of the Verein für Socialpolitik in Graz, participants of seminars in Basel and Brisbane, the KOF Research Seminar and the 2007 Barcelona Summer School on Fiscal Federalism, especially John D. Wilson, Albert Solé-Ollé, Kurt Schmidheiny and Lars P. Feld, for useful comments. 


\section{Introduction}

Since the seminal contribution of Tiebout (1956), a strong focus of the literature on fiscal federalism has been put on the analysis of market-like competition between jurisdictions. Tiebout showed that by voting with one's feet, there exists a mechanism that can reveal individual preferences for local public goods. Hence, fiscal decentralization appears to be efficiency enhancing, as it allows people with similar preferences concerning the provision of public goods to settle in communities that provide public goods at levels close to their preferences. ${ }^{1}$

Many of the results in this literature ${ }^{2}$ rest on the assumption that households differ in their preference for public goods, but have equal incomes. The influence of income heterogeneity on households' locational decisions and the local provision of public goods were first studied by Ellickson (1971) and Westhoff (1977). ${ }^{3}$ A core result of these models is the income segregation hypothesis. It postulates that if rich households esteem public goods less than poor households, fiscal federalism induces self sorting of the population by income. Following Schmidheiny (2006a), this clustering of rich and poor is even stronger in case of progressive tax schedules.

In this paper, we use community-level data from the Swiss canton of Zurich to study the influence of income taxes on the distribution of households according to their taxable income. The situation in Swiss cantons is quite unique, as the progressiveness of the tax schedule is set at the cantonal level, while the communities within the canton can set the effective tax burden by applying a tax multiplier to the cantonal tax schedule. This enables us to study the effects of tax differentials on the choice of residence within an economically and culturally homogeneous region. Using panel IV regressions covering the years 1991-2003 and 171 communities and spatial error regressions for the 171 communities in 2003, we find substantial evidence for the income segregation hypothesis in the canton of Zurich.

\footnotetext{
${ }^{1}$ Similarly, Oates (1972) argues in his "decentralization theorem" that there are no advantages associated with a centralized provision of public goods since differences in public good at the local level reflect differences in preferences across these jurisdictions.

${ }^{2}$ See Oates (1999), Wilson (1999) and Wilson and Wildasin (2004) for surveys.

${ }^{3}$ See also Ross and Yinger (1999) for a survey.
} 
The paper is organized as follows. The next section discusses previous theoretical and empirical findings. Section 3 gives an introduction to the tax system in Switzerland and in the Canton of Zurich. The fourth section presents the data. The results of the empirical analysis are discussed in section 5. Section 6 concludes.

\section{Theoretical Foundations and Empirical Evidence}

Tiebout's (1956) paper on the efficiency properties of fiscally induced migration has inspired many scholars in different fields of the public finance literature (see Oates, 2006 for an overview). The segregation hypothesis is one of the central propositions in multi-community models in the tradition of Tiebout. Endogenous segregation means that different people choose different locations in equilibrium. While the Tiebout model focuses on heterogeneity of preferences, Ellickson (1971) and Westhoff (1977) focus on income as the main cause of difference. Several mechanisms have been proposed that explain why rich households make different choices than poor households (see Ross and Yinger, 1999, for property tax models and Schmidheiny, 2002, for income tax models). Similar to the classic Tiebout model, one strand of the literature argues that rich and poor households differ in their preferences for public goods, which in turn will induce income sorting if tax rates, and hence levels of public goods provision, differ among jurisdictions. Another strand of the literature investigates the effect of the income elasticity for housing and the stylized fact that housing prices are typically higher in low tax communities (Epple, Filimon and Romer, 1993, Stadelmann and Billon, 2009). If housing is a normal good, housing expenditure becomes less important with increasing income, which means that rich households will benefit more from low taxes than they will lose from high housing prices. These studies, however, have assumed that tax rates are flat. In two recent papers, Schmidheiny (2006a) and Schmidheiny and Hodler (2006) draw on the empirical fact that income taxes are progressive and that local jurisdictions can often only set tax levels within a given tax scheme. High income households are then more likely to choose low tax communities, as their tax burden is relatively higher due to the progressiveness of the tax schedule.

Except for the two latter papers, the studies discussed above suggest strict income sorting, which is not observed empirically. De Bartolome and Ross (2003) solve this issue by introducing commuters and commuting cost into a model of fiscal competition and derive multiple equilibria with both income sorting and income mixing. Schmidheiny (2006b) derives imper- 
fect income segregation in a model where households differ in both income and preferences for housing.

The segregation hypothesis of the Tiebout type models has been challenged by a number of empirical studies. A first strand of research investigates the equilibrium predictions of multicommunity models using data on aggregate community characteristics.

Epple and Sieg (1999) and Epple, Romer and Sieg (2001) estimate the household preference parameters of a full equilibrium model where the local income distribution and local policy variables are simultaneously determined. They show that the differing income quantiles across 92 communities in the Boston area can be explained by the model predictions. Using data from US federal states, Bakija and Slemrod (2004) find that wealthy retirees change their state of residence to avoid high state taxes. Feld and Kirchgässner (2001) regress the share of seven income classes in Swiss cantons and main cities on income tax rates. They find a strong negative relationship between the tax rate and the share of rich households.

Schmidheiny (2006a) studies the locational choice of households in the Swiss metropolitan region of Basel and finds that rich households are substantially more likely to move to low tax communities than poor households.

The study closest to ours is Schmidheiny and Hodler (2006) who simulate a model of locational choice with progressive taxes at the federal level and a local tax multiplier using income and tax data from the canton of Zurich. Schmidheiny and Hodler's study generates two main insights. First, their model, calibrated with real-life values from the canton of Zurich, produces income sorting effects, and second, they find that, due to income sorting, the resulting actual tax progressiveness is lower than intended by the cantonal tax scheme, as high income individuals are more likely to reside in low tax communities, while low income individuals tend to live in high tax communities, which flattens the effective progressiveness of the tax scheme relative to the intended progressiveness.

In this paper, we show that income sorting effects are not only an outcome of a theoretical model, but can also be observed empirically in the case of the Zurich metropolitan area. To our best knowledge, we are the first to study income sorting using panel data from a small ${ }^{4}$ and culturally homogeneous region. Hence, we are not only able to make use of crosssectional variation, as is the case in e.g. Feld and Kirchgässner (2001), but can also take ac-

\footnotetext{
${ }^{4}$ The Canton of Zurich with its 171 communities is only slightly larger than London, UK.
} 
count of variations in tax rates and income shares over time. Unlike the previous literature, by using data from one single canton we avoid having to take account of factors determining locational decisions that are hard to measure or even not measurable, such as differences in mentality, attachment to the local community, family ties, or differences in the school system.

\section{Tax Competition in the Canton of Zurich}

Switzerland has a federalist constitution granting tax autonomy to the sub-federal governments. The Swiss federation consists of 26 states, the so-called cantons. The cantons are divided into roughly 3,000 communities of varying size, population, culture and language. All three state levels finance their expenditures essentially by their own taxes and fees. While the federal government is mainly financed by indirect taxes such as VAT, customs duties and excise dues, the cantons and communities largely rely on direct taxes. Income taxes account for $60 \%$ of cantonal and $84 \%$ of communal tax revenue. However, in addition the federal government levies a highly progressive and profit-yielding income tax which - in return for $17 \%$ of the revenues - is administrated by the cantons and has an equalizing effect across cantons. Second, a withholding tax on capital income by $35 \%$ is levied and will be refunded in case of declaration in the income tax form (Feld, 2000).

The cantons organize their tax systems autonomously within the constitutional requirements and legal specifications by the federal harmonization law. For example, they decide upon the level of income and corporate taxes and the degree of tax progression as well as the level of tax exemptions (Feld, 2000).

The individual communities in turn can set a tax multiplier for income and corporate taxes on the cantonal tax tariff. The communal income tax is then the cantonal tax rate multiplied by the communal tax multiplier. Income is taxed at the community of residence, which has led to the grouping of low tax suburban communities around large Swiss cities such as Basel and Zurich. Figure 1 displays the distribution of the local income tax multiplier among the 171 local communities of the canton Zurich for the fiscal year 2008 (Appendix 1b shows the tax progression of the cantonal tariff). 


\section{Figure 1: Local income tax burden in the Zurich metropolitan area}

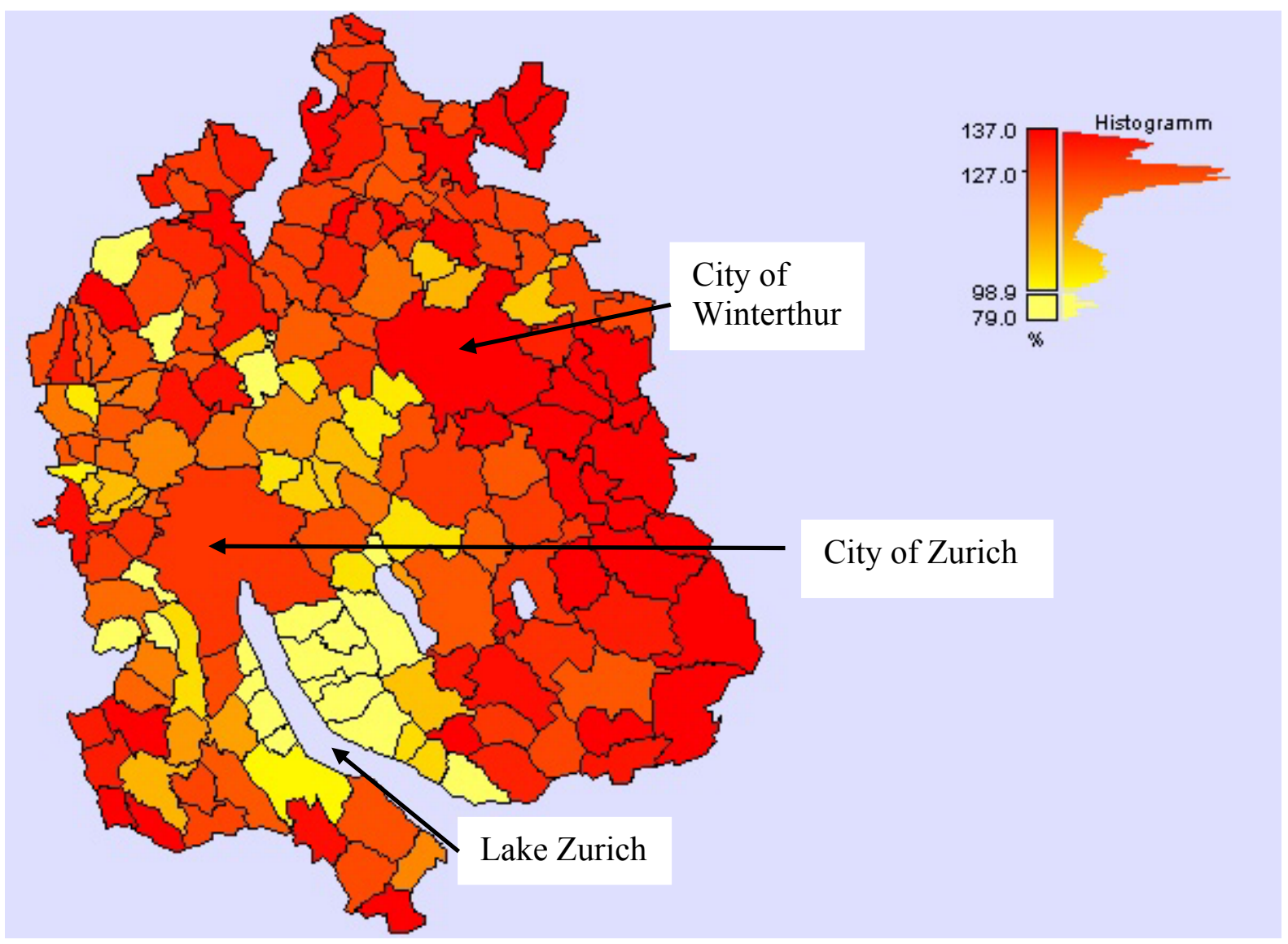

As Figure 1 reveals, the light-colored low-tax communities are sorted around the lake of $\mathrm{Zu}$ rich, whereas the dark-colored high-tax communities are located near Winterthur (for a more detailed map of the canton Zurich see Appendix 1). Compared to Figure 1, Figure 2 displays the corresponding local per capita tax revenues. The picture is very similar with a simple correlation coefficient of -0.77 : the local communities around the shores of Lake Zurich, especially the districts of Meilen and Horgen generate high per capita tax revenues while the tax capacity of the region around the city of Winterthur is much weaker. 
Figure 2: Local income tax revenues per capita in the Zurich metropolitan area

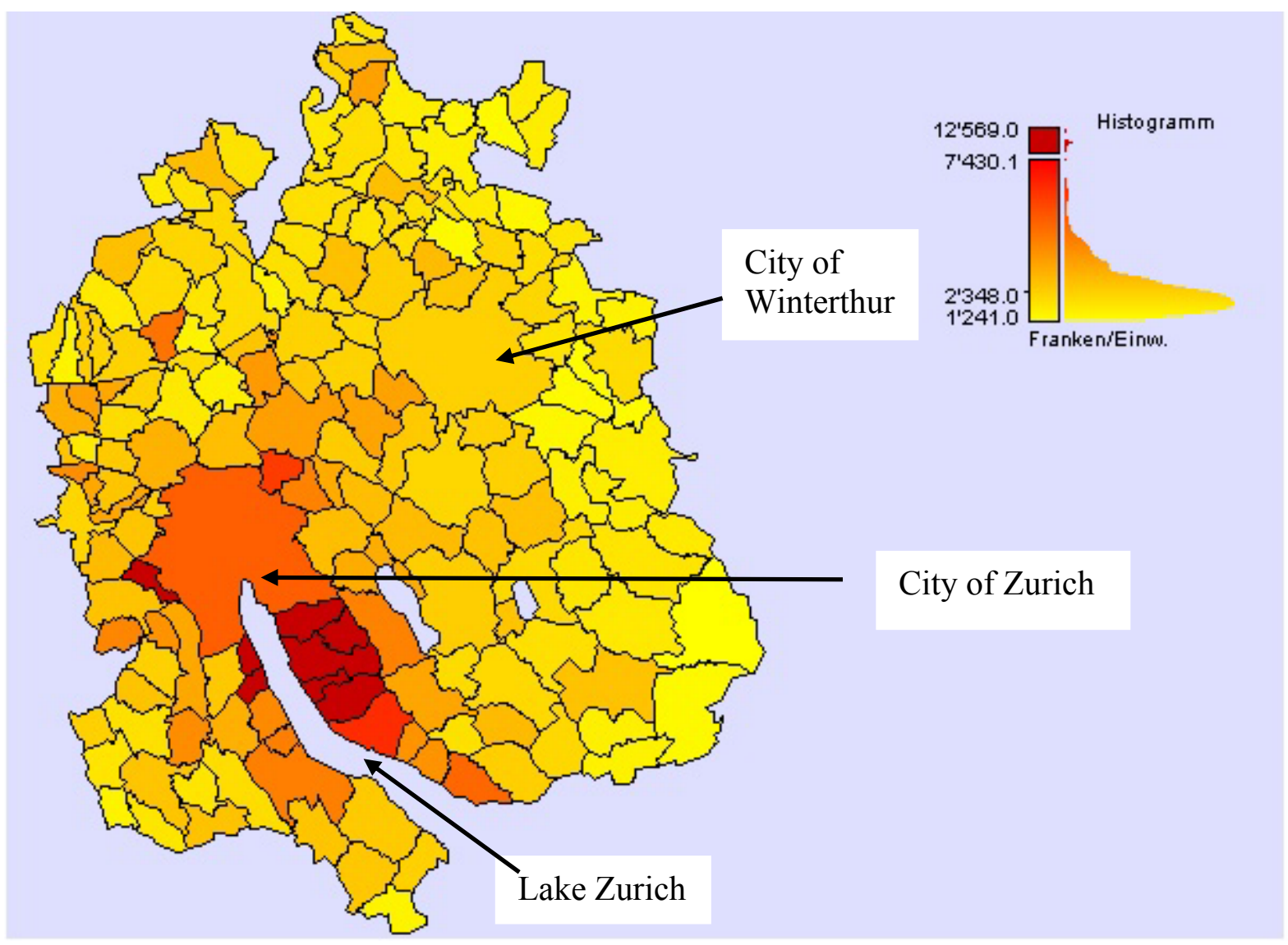

Tax competition in many countries is constrained by tax equalization programs. This is also the case in Switzerland on the federal as well as on the cantonal level (Schaltegger and Frey, 2003). In the canton of Zurich, for example, there are horizontal and vertical tax equalization programs that limit tax competition among communities: First, there is a program that redistributes tax revenues from the communities with the highest per capita tax bases to those with the lowest. Second, the canton of Zurich subsidizes the communities with the highest tax multipliers. Despite the existence of tax equalization schemes, differences in local taxation are still substantial. In the canton of Zurich, the tax multiplier for the fiscal year 2008 of communities with the highest tax multiplier (137 per cent) is almost 1.75 times higher than that of the community with the lowest tax multiplier (79 per cent), with an arithmetic mean of 121.4 per cent and a median of 127 per cent.

\section{Data and Empirical Strategy}

In this study, we use community level data from all 171 communities, grouped in 12 different districts in the Swiss canton of Zurich (for summary statistics see Appendix 2). We choose 
the canton of Zurich for our analysis, as the canton is the core economic region of Switzerland and attracts the largest share of immigration and intra-Swiss relocation; i.e. the number of locational choices to be done in the canton of Zurich can be assumed to be substantial. Data were collected from the Swiss Federal Office of Statistics, the Swiss Department of Finance, and the Zurich Cantonal Office of Statistics.

The dependent variables are the shares of different income groups in the population of a community. Since the income group ratios vary between zero and one and are therefore censored, they are transformed to log odds. If $p$ is the share of an income group of a community, then $p /(1-p)$ is the corresponding odds, and the logit of the share is the natural logarithm of the odds.

In the original source, there exist 14 classes of individual taxable income, which have been set by the cantonal statistical office. Data on income classes are available for the years 1991, 1995, 1999 and 2003. The box plot in Figure 3 shows the average shares of the 14 income classes in the population among the 171 local communities in the Zurich metropolitan area over the whole period of observation.

Figure 3: Boxplot: income shares for 14 income classes over 171 local communities

\begin{tabular}{|rr|}
\hline Income class & $\begin{array}{c}\text { Swiss Francs p.a. and } \\
\text { p.c. (in thousands) }\end{array}$ \\
\hline 1 & 0 \\
2 & $0.0001-9999$ \\
3 & $10-19.9999$ \\
4 & $20-29.9999$ \\
5 & $30-39.9999$ \\
6 & $40-49.9999$ \\
7 & $50-59.9999$ \\
8 & $60-69.9999$ \\
9 & $70-79.9999$ \\
10 & $80-89.9999$ \\
11 & $90-99.9999$ \\
12 & $100-149.9999$ \\
13 & $150-199.9999$ \\
14 & $>200.000$ \\
\hline
\end{tabular}

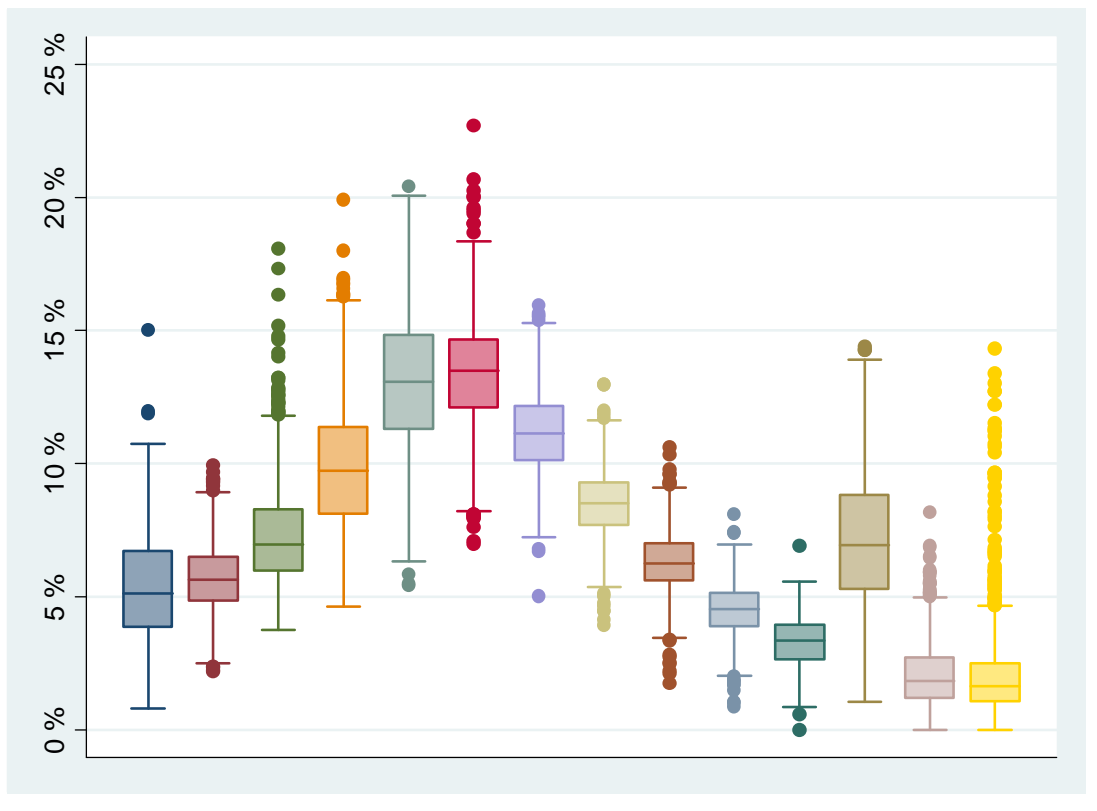

As our main explanatory variables, we use the local tax multiplier and the average tax multiplier of the other communities in the same district. If there exists inter-jurisdictional sorting according to the incentives given by tax competition with a progressive tax rate and varying tax multipliers, we expect a negative impact of the own tax multiplier on the share of high income residents and vice versa for low-income residents. For the average tax multiplier of 
the neighboring communities, the opposite should appear as long as there is tax competition: the share of high-income residents is positively associated with high tax burdens in neighboring communities and vice versa for low-income residents.

As control variables, we first use the local unemployment rate. Unemployment is a proxy for the business cycle, which is mostly determined at the federal level. Ignoring the unemployment rate would bias the results for our analysis of income sorting, as a move from employment to unemployment is an exogenous and in most cases temporary move from a higher income group into the low income group, and not an endogenous change in the share of the low income group caused by the choice of a residential location. Second, since the level of publicly provided goods may influence residential decisions ${ }^{5}$ we include the following variables: per capita payments to the cantonal public transport association, the share of pupils in local public schools, the share of locally practicing physicians, locally targeted per capita transfer payments from the cantonal fiscal equalization scheme and a dummy-variable for highway connectivity. Third, residential decisions are supposed to be influenced by the land price, which is consequently included in the regressions. Fourth, since tax rates are politically defined, the ideological position of the electorate may also be associated with residential decisions. To capture this aspect, we include the local vote-share of the largest Swiss party, the right-wing SVP (Swiss People's Party) on total votes for the election of the cantonal parliament. Also, the local capacity to finance public goods by government's per capita net wealth as well as public debt per capita can be seen as a reason for residential decisions (Eichenberger and Stadelmann, 2009). Finally, we include socio-demographic variables, namely total population and the share of elderly inhabitants (over age 65), the share of young inhabitants (under age 15), share of net migration in total population and the share of foreigners.

\section{Empirical Analysis}

In order to test the interjurisdictional sorting hypothesis, we regress the community's tax multiplier and the average neighboring tax multiplier in the district and the above mentioned con-

\footnotetext{
${ }^{5}$ See e.g. Stadelmann (2009).
} 
trol variables on the shares of 14 income classes in the local communities. The following 14 equations are estimated:

$$
\ln \left[p_{g i t} /\left(1-p_{g i t}\right)\right]=\beta T_{i t}+\delta T_{j t}+X_{i t}+\varepsilon_{i t}
$$

where the index $i$ refers to the local communities within the territory of the canton of Zurich $(i=1, \ldots, 171), j$ denotes the average local community of the 12 districts within the canton Zurich $(j=1, \ldots, 12)$ and the index $t$ refers to the fiscal year $(t=1991,1995,1999,2003)$. In $\left[p_{\text {git }} /\left(1-p_{\text {git }}\right)\right]$ represents the share of income class $g(g=1, \ldots, 14)$ among all taxpayers in a community $i$ in year $t . \beta, \delta$ and $\gamma$ are unknown parameters and $\varepsilon_{i t}$ is an error term. $X_{i t}$ is a matrix of explanatory variables specific to community $i$ in year $t$.

The Davidson-MacKinnon test of exogeneity with a value of 0.638 ( $p$-value $=0.528$ ) indicates endogeneity of the tax multipliers and the land prices. ${ }^{6}$ To tackle the problem, we use an instrumental variables (IV) method. As instruments we use distance to the city of Zurich, a dummy variable if a community has a train station, and dummy variables if the community is situated at the lake Zurich or the lake Greifensee. To take account of the panel structure of the data, we perform fixed effects regressions over the 12 districts. In a first step, we run regressions including the full set of control variables described above. We then follow a general-tospecific approach eliminating variables (community net worth, tax revenue per capita ${ }^{7}$ ) that turn out insignificant in all regression sequentially. Theoretically, we expect higher tax rates in communities with a train station and direct connection to the central city as an important public good in the Zurich metropolitan area. In the case of land prices, we expect a positive correlation with the view on Lake Zurich and the Lake Greifensee in the suburban area of Zurich, and a negative correlation with distance to Zurich. The first-stage results in Table $1^{8}$ support the relevance of our instruments. We find that taxes are lower in communities located at Lake Greifensee, while taxes are higher in communities that are further away from the city, and in communities that have a train connection. Concerning land prices, we find that prices are significantly higher in communities situated at Lake Zurich, while they are lower in

\footnotetext{
${ }^{6}$ The test statistics correspond to income class 10 (taxable income $80-89.9999$ p.a.). Test for other income classes reject exogeneity of tax multipliers and land prices as well.

${ }^{7}$ Public debt per capita however is significant, indicating evidence for the hypotheses put forth in Eichenberger and Stadelmann (2009).

${ }^{8}$ First stage results for all 14 income classes are given in Tables 1A and 1B.
} 
communities located at Lake Greifensee, and in communities that are further away from the city.

Table 1C reports the results of our analysis: in line with the prediction of the theory, we find a significantly negative relationship between local tax multipliers and the share of high income earners residing in a community, and a significantly positive relationship with the share of low income earners. Very much the same applies for neighbor tax multipliers: there is a significant positive effect of neighboring tax multipliers on the share of own high income earners and vice versa for low income earners in the own local community. High income individuals seem to esteem public transport more than low income earners, which is somewhat contrary to our theoretical considerations, but can be explained by the fact that high income earners are more likely to be commuters working in the city of Zurich, while low income earners are more likely to work in their community of residence and are hence not in need of public transportation. In the case of highway access, it is the middle class which esteems close connectivity, while high income earners prefer communities with a larger number of local physicians.

Table 1: Results of first stage regression (income class 10)

\begin{tabular}{|c|c|c|c|c|}
\hline Instruments & Tax multiplier & Land price & Relevance tests & \\
\hline Lake Zurich & $\begin{array}{r}-4.916 \\
{[1.34]}\end{array}$ & $\begin{array}{r}374.762 * * * \\
{[6.86]}\end{array}$ & $\begin{array}{l}\text { Anderson canon. } \\
\text { corr. LM statistic }\end{array}$ & $\begin{array}{r}14.11 \\
(\mathrm{p}-\mathrm{val} .=0.007)\end{array}$ \\
\hline Distance to Zurich & $0.937 * * *$ & $-8.870 * * *$ & & \\
\hline Lake Greifensee & $\begin{array}{r}{[10.80]} \\
-9.823 * * \\
{[2.09]}\end{array}$ & $\begin{array}{r}{[6.37]} \\
-314.162 * * * \\
{[4.36]}\end{array}$ & $\begin{array}{l}\text { Anderson-Rubin } \\
\text { Wald test }\end{array}$ & $\begin{array}{r}4.56 \\
(p-v a l=0.001)\end{array}$ \\
\hline Train Station & $\begin{array}{r}1.156 \\
{[1.38]}\end{array}$ & $\begin{array}{r}32.991 * * \\
{[2.39]}\end{array}$ & & \\
\hline \multicolumn{5}{|c|}{ Summary results for first-stage regressions } \\
\hline & Shea Partial R2 & Partial R2 & $\mathrm{F}(4,661)$ & p-value \\
\hline Land price & 0.075 & 0.22 & 28.84 & 0 \\
\hline $\begin{array}{l}\text { Tax multiplier } \\
\text { * significant at } 10 \% \text {; ** sign }\end{array}$ & $\begin{array}{r}0.04 \\
\text { ificant at } 5 \% ; * * * \text { signifi }\end{array}$ & nt at $1 \%$ & 46.07 & 0 \\
\hline
\end{tabular}


Socio-demographic variables play an important role for inter-jurisdictional sorting: highincome communities have less foreigners and more elderly residents ${ }^{9}$. The influence of financial transfers from both the state and between the communities is found to have almost no impact on the shares of the income groups in a community. The same applies for net migration, government ideology, debt levels and the share of pupils. Land prices, unsurprisingly, are found to have a negative effect on some of the lower income classes, and a positive (but hardly significant) effect in the upper classes. Airport noise seems to reduce the share of very high income earners in a community and to raise the share of people with mid-range taxable income, while reducing the share of people at the very low end of the income distribution.

\section{Parsimonious Model}

As a robustness check, we leave out all variables concerning public finances except for the tax rates, all variables that proxy the amount of public goods provision and all sociodemographic variables except for the unemployment rate and population size in the second stage estimation. Our main results, presented in Table 2, remain robust to this drastic change in the regression setup. Again, we find a community's own tax multiplier to be positively related to the shares of low income earners, and negatively related to the share of high income earners. The reverse result holds for the tax rates of the district neighbors: a higher average tax rate in neighboring communities is associated with lower share of low income earners in the community, and a higher share of high income earners.

\section{Spatial Correlation}

In the estimations presented in the above section, we tackled the endogeneity problem arising from the fact that land prices and tax rates are endogenous to the income of a community's inhabitants. In this section, we address two other issues. The first is the possibility that a community's income distribution is endogenous to the income distribution of neighboring communities, which may be the case because of clustering effects caused by e.g. an increased attractiveness of community A due to a positive socio-demographical change in the neighbor-

\footnotetext{
${ }^{9}$ Note that we are looking at taxable income. Public pensions are only partially taxed.
} 
ing community B. A second related issue is spatial correlation of the error terms which is caused by omitted spatial variables.

For our analysis, we use two different spatial weighting matrices. First, we employ the inverse of the distance between the communities, and second, we use a matrix containing a 1 if the communities share a common border and 0 otherwise. When computing the weighting scheme, the matrices are row standardized.

Using the standard specification test as discussed in Anselin et al. (1996), we find that we can exclude a spatial lag model. The test indicate however the existence of spatial correlation in the error term. This only holds when we apply the inverse distance matrix as spatial weights. Using the matrix considering only neighboring communities, we find no evidence for spatial correlation. A first conclusion is thus that individuals do not care about tax rates of neighboring communities in choosing their place of residence, but take the whole canton, or at least communities further away than the neighboring community, into account.

As the tests however suggest spatial dependency in the error terms, we estimate a spatial lag model as described in Anselin (1988) and Anselin and Bera (1998). The equations are estimated using Maximum Likelihood take the following form

$$
\begin{gathered}
\ln \left[p_{g i} /\left(1-p_{g i}\right)\right]=\alpha+\beta T_{i}+\delta X_{i}+\varepsilon_{I,} \\
\text { with } \mathcal{\varepsilon}=\lambda W \mathcal{E}+u
\end{gathered}
$$

where $\ln \left[\mathrm{p}_{\mathrm{gi}} /\left(1-\mathrm{p}_{\mathrm{gi}}\right)\right]$ are the log odds of the respective income share $\mathrm{g}, \boldsymbol{\varepsilon}$ is a vector of spatially autocorrelated error terms, $u$ is a vector of i.i.d. errors, $T_{i}$ is the tax multiplier of community $\mathrm{i}$ and $\mathrm{X}_{\mathrm{i}}$ is a vector of observations of the other explanatory variables and $\lambda, \beta$ and $\delta$ are parameters.

The results, which are presented in Table 3, show that our main finding is robust in this setup. Again, we find that high tax multipliers cause a larger share of low income earners, indicated by the positive and significant coefficient of the tax multiplier in the columns for income classes up to 50.000 Swiss Franks, and the negative and significant coefficient for the income classes above 80.000 Swiss Franks. Furthermore, for the higher income classes the importance of the tax rate in the choice of location seems to increase, as indicated by the (absolute) increase of the coefficient from middle to high income classes. The findings on the control variables remain also robust. 


\section{Conclusion}

In this paper, we have investigated the empirical validity of the inter-jurisdictional income sorting hypothesis, which is a core result of the theoretical tax competition literature. It states that in a system with fiscal federalism, individuals differing in income and preferences for public goods and/or housing will self-select into different communities, where communities differ in income tax rates. This self-selection process will then lead to substantial differences in the income distributions between the communities.

In our empirical analysis covering 171 communities over the share of 14 income classes on the whole population in the Swiss canton of Zurich, we have found ample evidence for the income segregation hypothesis. We provide empirical evidence that high income earners are more likely to reside in low tax communities especially if neighboring communities in the same district have higher taxes. The opposite holds for low-income earners: they settle more likely in high tax communities especially, if neighboring communities offer lower taxes.

While the tax competition literature in the Tiebout tradition suggests that this kind of income sorting enhances overall efficiency in the economy, the literature on education highlights the negative aspects of income sorting. In general, advocates argue that fiscal federalism allows tailoring public goods towards the specific needs of local residents, enhances efficiency while reducing inefficiency in public administration due to the pressure created by systems competition. In addition, the more homogenous a local community, the more targeted fiscal equalization schemes across the canton can work and the more efficiently the redistributive capacity of such a transfer program will be. Critics argue on the other hand, that with fiscal federalism it is found that the opportunities of an individual are highly correlated with his or her neighborhood and social background. An uneven distribution of high and low income individuals between communities is thus likely to reduce human capital accumulation and social mobility, and to produce persistent inequality and poverty traps. These social problems might be enforced by increasing worldwide economic integration. The literature, however, suggests that economic globalization leads to an increasing wage gap between low-skilled and highskilled workers, and to an increasing taxation of the relatively more immobile factor of production, namely labor.

In combination with the results of the income sorting literature, increasing globalization can be expected to lead to an increase in income sorting in countries with income tax competition at the local level, yielding new challenges for both politicians and researchers. 


\section{References}

Anselin, Luc (1988): "Spatial Econometrics: Methods and Models". Kluwer Academic Publishers, Dordrecht, The Netherlands.

Anselin, Luc, Bera, Anil K., Florax, Raymond and Mann J. Yoon (1996): "Simple Diagnostic Tests for Spatial Dependence”, Regional Science \& Urban Economics 26(1), 77-104.

Anselin, Luc and Anil K. Bera (1998): "Spatial Dependence in Linear Regression Models With an Introduction to Spatial Econometrics" in: Ullah, A. and Giles, D. E., editors, Handbook of Applied Economic Statistics, 237-289. Marcel Dekker, New York.

Bakija, Jon and Joel Slemrod (2004): "Do the Rich Flee from High State Taxes? Evidence from Federal Estate Tax Returns", NBER Working Paper 10645, National Bureau of Economic Research.

de Bartolome, Charles A. M. and Stephen L. Ross (2003): "Equilibria With Local Governments and Commuting: Income Sorting vs. Income Mixing," Journal of Urban Economics $54,1-20$.

Eichenberger, Reiner and David Stadelmann (2009): "Consequences of Debt Capitalization: Property Ownership and Debt/Tax Choice," CREMA Working Paper Series 2009-08, Center for Research in Economics, Management and the Arts (CREMA).

Ellickson, Bryan (1971): “Jurisdictional Fragmentation and Residential Choice", American Economic Review 61(2), 334-339.

Epple, Dennis and Holger Sieg (1999): "Estimating Equilibrium Models of Local Jurisdictions," Journal of Political Economy 107, 645-68.

Epple, Dennis, Radu Filimon, and Thomas Romer (1993): "Existence of Voting and Housing Equilibrium in a System of Communities with Property Taxes," Regional Science and Urban Economics 23, 585-610.

Epple, Dennis, Thomas Romer and Holger Sieg (2001): "Interjurisdictional Sorting and Majority Rule: An Empirical Analysis," Econometrica 69, 1437-1465.

Feld, Lars P. (2000): "Steuerwettbewerb und seine Auswirkungen auf Allokation und Distribution: Ein Überblick und eine empirische Analyse für die Schweiz," Mohr Siebeck, Tübingen.

Feld, Lars P. and Gebhard Kirchgässner (2001): "Income Tax Competition at the State and Local Level in Switzerland," Regional Science and Urban Economics 31(2-3), 181-213.

Oates, Wallace E. (1972): “Fiscal Federalism,” New York, Harcourt Brace Jovanovich.

Oates, Wallace E. (1999): “An Essay on Fiscal Federalism”, Journal of Economic Literature $37,1120-1149$.

Oates, Wallace E. (2006): "The Many Faces of the Tiebout Model," in The Tiebout Model at Fifty: Essays in Public Economics in Honor of Wallace Oates, ed. William A. Fischel, 2145, Cambridge, Mass.: Lincoln Institute of Land Policy.

Ross, Stephen and John Yinger (1999): "Sorting and Voting: A Review of the Literature on Urban Public Finance”, in: Paul Ceshire and Edwin S. Mills (eds.), Handbook of Regional and Urban Economics, Vol. 3, Amsterdam: North-Holland. 
Schaltegger, Christoph A. and René L. Frey (2003): "Finanzausgleich und Föderalismus: Zur Neugestaltung der föderalen Finanzbeziehungen am Beispiel der Schweiz," Perspektiven der Wirtschaftspolitik 2, 239-258.

Schmidheiny, Kurt (2002): "Income Stratification in Multi-Community Models", VWI Discussion Paper 15-02, University of Bern.

Schmidheiny, Kurt (2006a): "Income Segregation and Local Progressive Taxation: Empirical Evidence from Switzerland”, Journal of Public Economics 90, 429-458.

Schmidheiny, Kurt (2006b): "Income Segregation from Local Income Taxation When Households Differ in Both Preferences and Income", Regional Science and Urban Economics 36, 270-299.

Schmidheiny, Kurt and Roland Hodler (2006): "How Fiscal Decentralization Flattens Progressive Taxes", Finanzarchiv/Public Finance Analysis 62(2), 281-304.

Stadelmann, David (2009): "Which Factors Capitalize into House Prices? A Bayesian Averaging Approach," CREMA Working Paper Series 2009-10, Center for Research in Economics, Management and the Arts (CREMA).

Stadelmann, David and Steve Billon (2009): "Capitalization of Fiscal Variables over Space and Time", University of Fribourg, mimeo.

Tiebout, Charles M. (1956): "A Pure Theory of Local Expenditures", Journal of Political Economy 64(5), 416-424.

Westhoff, Frank (1997): "Existence of Equilibria in Economies with a Local Public Good", Journal of Economic Theory 14, 84-112.

Wilson, John D. (1999): “Theories of Tax Competition”, National Tax Journal, 53, 269-304.

Wilson, John D. and David E. Wildasin (2004): "Capital Tax Competition: Bane or Boon", Journal of Public Economics, 88, 1065-1091. 
Table 1A, First stage panel regression, 1991-2003, 171 communities, dependent variable: tax multipliers

\begin{tabular}{|c|c|c|c|c|c|c|c|c|c|c|c|c|c|c|}
\hline Income Class, Swiss Francs p.a. & 0 & $0.0001-9999$ & $10-19.9999$ & $20-29.9999$ & $30-39.9999$ & 40-49.9999 & $50-59.9999$ & 60-69.9999 & 70-79.9999 & $80-89.9999$ & 90-99.9999 & $100-149.9999$ & $150-199.9999$ & $>200.000$ \\
\hline \multirow[t]{2}{*}{ Lake Zurich } & -4.916 & -4.916 & -4.916 & -4.916 & -4.916 & -4.916 & -4.916 & -4.916 & -4.916 & -4.916 & -4.912 & -4.916 & -4.871 & -4.887 \\
\hline & [1.34] & [1.34] & [1.34] & [1.34] & [1.34] & [1.34] & [1.34] & [1.34] & [1.34] & [1.34] & [1.34] & [1.34] & [1.33] & [1.34] \\
\hline \multirow[t]{2}{*}{ Distance to Zurich } & $0.937^{* * *}$ & $0.937^{* * *}$ & $0.937 * * *$ & $0.937^{* * *}$ & $0.937 * * *$ & $0.937 * * *$ & $0.937 * * *$ & $0.937^{* * *}$ & $0.937 * * *$ & $0.937 * * *$ & $0.938^{* * *}$ & $0.937^{* * *}$ & $0.939 * * *$ & $0.946 * * *$ \\
\hline & [10.80] & {$[10.80]$} & {$[10.80]$} & [10.80] & [10.80] & [10.80] & {$[10.80]$} & {$[10.80]$} & [10.80] & {$[10.80]$} & [10.79] & {$[10.80]$} & {$[10.74]$} & [10.84] \\
\hline \multirow[t]{2}{*}{ Lake Greifensee } & $-9.823^{* *}$ & $-9.823^{* *}$ & $-9.823^{* *}$ & $-9.823^{* *}$ & $-9.823^{* *}$ & $-9.823^{* *}$ & $-9.823 * *$ & $-9.823^{* *}$ & $-9.823^{* *}$ & $-9.823^{* *}$ & $-9.829^{* *}$ & $-9.823^{* *}$ & $-9.854^{* *}$ & $-9.796^{* *}$ \\
\hline & [2.09] & [2.09] & [2.09] & [2.09] & [2.09] & [2.09] & [2.09] & [2.09] & [2.09] & [2.09] & [2.09] & [2.09] & [2.10] & {$[2.08]$} \\
\hline \multirow[t]{2}{*}{ Train Station } & 1.156 & 1.156 & 1.156 & 1.156 & 1.156 & 1.156 & 1.156 & 1.156 & 1.156 & 1.156 & 1.164 & 1.156 & 1.151 & 1.113 \\
\hline & {$[1.38]$} & [1.38] & [1.38] & [1.38] & [1.38] & [1.38] & [1.38] & {$[1.38]$} & [1.38] & [1.38] & [1.39] & [1.38] & [1.37] & [1.32] \\
\hline \multirow[t]{2}{*}{ Constant } & $99.449 * * *$ & $99.449 * * *$ & $99.449 * * *$ & $99.449 * * *$ & $99.449 * * *$ & $99.449 * * *$ & $99.449 * * *$ & $99.449 * * *$ & $99.449 * * *$ & $99.449 * * *$ & $99.428 * * *$ & $99.449 * * *$ & $99.398 * * *$ & $99.338^{* * *}$ \\
\hline & [32.12] & [32.12] & [32.12] & [32.12] & [32.12] & [32.12] & [32.12] & [32.12] & [32.12] & [32.12] & [32.12] & [32.12] & [32.32] & [32.07] \\
\hline Observations & 684 & 684 & 684 & 684 & 684 & 684 & 684 & 684 & 684 & 684 & 683 & 684 & 680 & 681 \\
\hline \# of districts & 12 & 12 & 12 & 12 & 12 & 12 & 12 & 12 & 12 & 12 & 12 & 12 & 12 & 12 \\
\hline
\end{tabular}

Absolute value of $z$ statistics in brackets

$*$ significant at $10 \%$; * significant at $5 \%$; *** significant at $1 \%$

Table 1B, First stage panel regression, 1991-2003, 171 communities, dependent variable: land price

\begin{tabular}{|c|c|c|c|c|c|c|c|c|c|c|c|c|c|c|}
\hline Income Class, Swiss Francs p.a. & 0 & $0.0001-9999$ & $10-19.9999$ & $20-29.9999$ & $30-39.9999$ & $40-49.9999$ & $50-59.9999$ & $60-69.9999$ & $70-79.9999$ & $80-89.9999$ & $90-99.9999$ & $100-149.9999$ & 150-199.9999 & $>200.000$ \\
\hline \multirow[t]{2}{*}{ Lake Zurich } & $374.762 * * *$ & $374.762 * * *$ & $374.762 * * *$ & $374.762 * * *$ & $374.762 * * *$ & $374.762^{* * *}$ & $374.762 * * *$ & $374.762 * * *$ & $374.762 * * *$ & $374.762 * * *$ & $375.022 * * *$ & $374.762 * * *$ & $375.624 * * *$ & $375.610^{* * * *}$ \\
\hline & {$[6.86]$} & [6.86] & [6.86] & {$[6.86]$} & [6.86] & [6.86] & [6.86] & [6.86] & [6.86] & [6.86] & [6.86] & {$[6.86]$} & {$[6.87]$} & [6.89] \\
\hline \multirow[t]{2}{*}{ Distance to Zurich } & $-8.870^{* * * *}$ & $-8.870^{* * *}$ & $-8.870^{* * *}$ & $-8.870^{* * * *}$ & $-8.870 * * *$ & $-8.870^{* * * *}$ & $-8.870 * * *$ & $-8.870^{* * * *}$ & $-8.870^{* * * *}$ & $-8.870^{* * * *}$ & $-8.884^{* * * *}$ & $-8.870^{* * *}$ & $-9.000^{* * *}$ & $-9.054 * * *$ \\
\hline & {$[6.37]$} & {$[6.37]$} & {$[6.37]$} & {$[6.37]$} & {$[6.37]$} & [6.37] & {$[6.37]$} & {$[6.37]$} & {$[6.37]$} & [6.37] & [6.38] & [6.37] & [6.41] & {$[6.48]$} \\
\hline Lake Greifensee & $\begin{array}{l}-314.162^{* * *} \\
{[4.36]}\end{array}$ & $\begin{array}{l}-314.162^{* * *} \\
{[4.36]}\end{array}$ & $\begin{array}{l}-314.162^{* * * *} \\
{[4.36]}\end{array}$ & $\begin{array}{l}-314.162^{* * *} \\
{[4.36]}\end{array}$ & $\begin{array}{l}-314.162^{* * *} \\
{[4.36]}\end{array}$ & $\begin{array}{l}-314.162^{* * *} \\
{[4.36]}\end{array}$ & $\begin{array}{l}-314.162^{* * *} \\
{[4.36]}\end{array}$ & $\begin{array}{l}-314.162 * * * \\
{[4.36]}\end{array}$ & $\begin{array}{l}-314.162^{* * *} \\
{[4.36]}\end{array}$ & $\begin{array}{l}-314.162^{* * *} \\
{[4.36]}\end{array}$ & $\begin{array}{l}-314.367^{* * * *} \\
{[4.36]}\end{array}$ & $\begin{array}{l}-314.162 * * * \\
{[4.36]}\end{array}$ & $\begin{array}{l}-315.414 * * * \\
{[4.38]}\end{array}$ & $\begin{array}{l}-315.930^{* * *} \\
{[4.39]}\end{array}$ \\
\hline \multirow[t]{2}{*}{ Train Station } & $32.991 * *$ & $32.991 * *$ & $32.991 * *$ & $32.991 * *$ & $32.991 * *$ & $32.991 * *$ & $32.991 * *$ & $32.991 * *$ & $32.991 * *$ & $32.991 * *$ & $32.894 * *$ & $32.991^{* *}$ & $33.335 * *$ & $34.022 * *$ \\
\hline & [2.39] & [2.39] & {$[2.39]$} & {$[2.39]$} & [2.39] & [2.39] & {$[2.39]$} & [2.39] & [2.39] & [2.39] & {$[2.38]$} & [2.39] & {$[2.40]$} & {$[2.45]$} \\
\hline Constant & $\begin{array}{l}764.5577^{* * *} \\
{[20.06]}\end{array}$ & $\begin{array}{l}764.5577^{* * *} \\
{[20.06]}\end{array}$ & $\begin{array}{l}764.557^{* * *} \\
{[20.06]}\end{array}$ & $\begin{array}{l}764.557^{* * *} \\
{[20.06]}\end{array}$ & $\begin{array}{l}764.557^{* * *} \\
{[20.06]}\end{array}$ & $\begin{array}{l}764.557 * * * \\
{[20.06]}\end{array}$ & $\begin{array}{l}764.557^{* * *} \\
{[20.06]}\end{array}$ & $\begin{array}{l}764.557^{* * * *} \\
{[20.06]}\end{array}$ & $\begin{array}{l}764.557^{* * *} \\
{[20.06]}\end{array}$ & $\begin{array}{l}764.557^{* * * *} \\
{[20.06]}\end{array}$ & $\begin{array}{l}764.770 * * * \\
{[20.06]}\end{array}$ & $\begin{array}{l}764.5577^{* * *} \\
{[20.06]}\end{array}$ & $\begin{array}{l}765.769 * * * \\
{[20.09]}\end{array}$ & $\begin{array}{l}766.239 * * * \\
{[20.19]}\end{array}$ \\
\hline Observations & 684 & 684 & 684 & 684 & 684 & 684 & 684 & 684 & 684 & 684 & 683 & 684 & 680 & 681 \\
\hline \# of districts & 12 & 12 & 12 & 12 & 12 & 12 & 12 & 12 & 12 & 12 & 12 & 12 & 12 & 12 \\
\hline
\end{tabular}

Absolute value of $z$ statistics in brackets 
Table 1C, Second stage Panel IV regression results, district fixed effects, 1991-2003, 171 communities, instrumented variables: tax multiplier and land price

\begin{tabular}{|c|c|c|c|c|c|c|c|c|c|c|c|c|c|c|}
\hline Income Class, Swiss Francs p.a. & 0 & $0.0001-9999$ & 10-19.9999 & 20-29.9999 & 30-39.9999 & 40-49.9999 & $50-59.9999$ & $60-69.9999$ & 70-79.9999 & $80-89.9999$ & 90-99.9999 & $100-149.9999$ & 150-199.9999 & $>200.000$ \\
\hline \multirow[t]{2}{*}{ Tax multiplier } & $0.011^{*}$ & $0.007^{*}$ & 0.006 & $0.010^{* *}$ & $0.019^{* * *}$ & $0.011^{* * *}$ & 0 & -0.003 & -0.001 & $-0.008^{*}$ & $-0.021^{* * *}$ & $-0.028^{* * *}$ & $-0.051^{* * * *}$ & $-0.061^{* * *}$ \\
\hline & {$[1.72]$} & [1.79] & {$[1.38]$} & {$[2.14]$} & {$[4.63]$} & {$[3.54]$} & {$[0.16]$} & {$[1.04]$} & {$[0.28]$} & {$[1.86]$} & {$[3.57]$} & {$[3.78]$} & [4.33] & {$[3.81]$} \\
\hline \multirow[t]{2}{*}{ Land price } & 0.2 & 0.011 & $-0.264^{*}$ & $-0.487 * * *$ & -0.108 & -0.105 & -0.132 & 0.044 & 0.117 & 0.212 & 0.09 & 0.435 & 0.629 & $1.242^{* *}$ \\
\hline & {$[0.87]$} & {$[0.08]$} & {$[1.76]$} & {$[2.95]$} & {$[0.76]$} & {$[0.98]$} & {$[1.38]$} & {$[0.46]$} & {$[0.98]$} & {$[1.40]$} & {$[0.44]$} & [1.61] & [1.51] & {$[2.18]$} \\
\hline \multirow[t]{2}{*}{ Neighbor tax, district average } & -0.001 & $-0.003 * *$ & $-0.005 * * *$ & $-0.006 * * *$ & $-0.005 * * *$ & $-0.002 * *$ & 0.001 & $0.002 * * *$ & $0.002 * *$ & $0.004 * * *$ & $0.008 * * *$ & $0.014 * * *$ & $0.014 * * *$ & $0.018 * * *$ \\
\hline & {$[0.42]$} & {$[2.34]$} & {$[4.10]$} & {$[4.98]$} & [4.64] & {$[2.50]$} & {$[0.81]$} & {$[2.84]$} & {$[2.32]$} & {$[3.17]$} & {$[4.86]$} & {$[6.30]$} & {$[3.98]$} & {$[4.08]$} \\
\hline \multirow[t]{2}{*}{ Airport noise } & $-0.163 * * *$ & $-0.082 * * *$ & -0.016 & -0.039 & 0.013 & $0.084 * * *$ & $0.093^{* * *}$ & $0.082 * * *$ & 0.02 & 0.037 & 0.01 & -0.019 & $-0.154^{*}$ & $-0.255^{* *}$ \\
\hline & {$[3.22]$} & {$[2.64]$} & {$[0.58]$} & {$[1.22]$} & {$[0.45]$} & {$[3.65]$} & {$[4.83]$} & {$[4.46]$} & {$[0.65]$} & {$[1.43]$} & {$[0.27]$} & {$[0.38]$} & {$[1.95]$} & {$[2.45]$} \\
\hline \multirow[t]{2}{*}{ Share of elderly } & $1.695^{* * * *}$ & 0.601 & $2.155^{* * *}$ & $2.083^{* * *}$ & 0.359 & $-0.808^{* * * *}$ & $-1.067^{* * *}$ & $-1.160^{* * *}$ & $-2.123^{* * * *}$ & $-2.762 * * *$ & $-2.751 * * *$ & $-2.939 * * *$ & $-2.159 *$ & 1.99 \\
\hline & {$[2.67]$} & [1.54] & {$[5.55]$} & {$[4.91]$} & {$[0.93]$} & {$[2.68]$} & {$[4.04]$} & {$[4.65]$} & {$[6.68]$} & {$[6.65]$} & {$[4.76]$} & {$[4.00]$} & {$[1.76]$} & {$[1.22]$} \\
\hline \multirow[t]{2}{*}{ Share of young } & $-4.634 * * *$ & $-1.435^{* *}$ & 1.101 & 0.401 & $-1.384^{*}$ & $-1.149^{*}$ & $0.804 *$ & 0.477 & -0.644 & -0.1 & 1.653 & 0.996 & 3.298 & $5.824 * *$ \\
\hline & {$[3.93]$} & {$[2.20]$} & [1.54] & {$[0.51]$} & [1.92] & {$[1.88]$} & {$[1.73]$} & {$[1.04]$} & [1.09] & {$[0.14]$} & {$[1.53]$} & {$[0.72]$} & [1.51] & {$[2.07]$} \\
\hline \multirow[t]{2}{*}{ Net migration, perc. } & -0.098 & -0.47 & -0.663 & 0.128 & 0.37 & $0.696^{*}$ & 0.15 & 0.044 & -0.217 & $-1.368^{* *}$ & -0.051 & 0.365 & -0.844 & -0.219 \\
\hline & {$[0.11]$} & {$[0.83]$} & {$[1.24]$} & {$[0.23]$} & {$[0.68]$} & {$[1.74]$} & {$[0.39]$} & {$[0.10]$} & {$[0.39]$} & {$[2.04]$} & {$[0.06]$} & {$[0.36]$} & {$[0.54]$} & {$[0.11]$} \\
\hline \multirow[t]{2}{*}{ Share of pupils } & -2.292 & -0.76 & -0.54 & -1.898 & -0.373 & -0.398 & $2.044 * * *$ & 1.091 & 0.658 & 0.64 & 1.989 & 0.052 & 2.272 & 2.55 \\
\hline & {$[1.22]$} & {$[0.62]$} & {$[0.46]$} & {$[1.29]$} & {$[0.24]$} & {$[0.38]$} & {$[2.71]$} & {$[1.21]$} & {$[0.64]$} & {$[0.51]$} & {$[0.88]$} & {$[0.02]$} & {$[0.52]$} & {$[0.43]$} \\
\hline \multirow[t]{2}{*}{ Contributions to public transport } & $-3.046^{* * *}$ & $-1.269 * *$ & $1.005^{* *}$ & -0.699 & $-1.055^{* *}$ & -0.192 & -0.156 & -0.276 & -0.765 & -0.34 & 0.527 & $1.915^{* *}$ & $3.505^{* *}$ & $3.506 * *$ \\
\hline & {$[3.52]$} & {$[2.19]$} & {$[2.02]$} & {$[1.35]$} & {$[2.34]$} & {$[0.55]$} & {$[0.44]$} & {$[0.52]$} & {$[1.13]$} & {$[0.46]$} & {$[0.75]$} & {$[2.17]$} & {$[2.46]$} & {$[2.11]$} \\
\hline \multirow[t]{2}{*}{ Physicians p.c. } & -5.772 & -22.415 & -24.398 & -2.378 & -19.311 & -14.175 & 5.614 & 14.491 & -4.225 & 19.8 & $38.081^{*}$ & $46.786^{*}$ & 56.796 & 47.478 \\
\hline & {$[0.23]$} & {$[1.38]$} & {$[1.54]$} & {$[0.16]$} & {$[1.32]$} & {$[1.11]$} & {$[0.54]$} & {$[1.42]$} & {$[0.36]$} & {$[1.31]$} & {$[1.70]$} & {$[1.76]$} & {$[1.30]$} & {$[0.83]$} \\
\hline \multirow[t]{2}{*}{ Share of foreigners } & -0.001 & -0.003 & $0.004 * *$ & $0.007 * * *$ & $0.010^{* * *}$ & $0.005^{* * *}$ & 0.001 & 0.001 & -0.002 & $-0.008 * * *$ & $-0.011 * * *$ & $-0.017^{* * * *}$ & $-0.020^{* * *}$ & $-0.021 * * *$ \\
\hline & {$[0.37]$} & {$[1.60]$} & {$[2.24]$} & {$[3.68]$} & {$[5.35]$} & {$[3.37]$} & {$[1.33]$} & {$[1.30]$} & {$[1.10]$} & {$[4.34]$} & {$[4.74]$} & {$[5.26]$} & {$[4.16]$} & {$[3.25]$} \\
\hline \multirow[t]{2}{*}{ Share of right wing party } & $0.006^{* * *}$ & 0.002 & $-0.003^{* *}$ & 0.001 & 0 & $-0.002 *$ & -0.001 & 0.001 & $-0.002 * *$ & 0 & -0.001 & 0 & $0.007 * *$ & $0.010^{*}$ \\
\hline & {$[3.43]$} & {$[1.36]$} & {$[2.32]$} & {$[0.65]$} & {$[0.09]$} & {$[1.78]$} & {$[0.62]$} & {$[1.26]$} & {$[2.03]$} & {$[0.07]$} & {$[0.61]$} & {$[0.05]$} & {$[2.07]$} & {$[1.86]$} \\
\hline \multirow[t]{2}{*}{ Population } & -0.002 & 0 & $0.002 * * *$ & $0.002 * *$ & 0 & 0 & 0.001 & 0 & -0.001 & -0.001 & 0 & -0.002 & -0.001 & -0.002 \\
\hline & [1.64] & {$[0.55]$} & {$[2.70]$} & {$[2.05]$} & {$[0.14]$} & {$[0.12]$} & {$[1.10]$} & {$[1.08]$} & {$[1.46]$} & {$[1.62]$} & {$[0.02]$} & {$[1.10]$} & {$[0.28]$} & {$[0.75]$} \\
\hline \multirow[t]{2}{*}{ unemployment rate } & $0.092 * * *$ & $-0.029 * * *$ & $-0.077 * * *$ & $-0.099^{* * *}$ & $-0.073 * * *$ & $-0.016^{* *}$ & $0.022 * * *$ & $0.023 * * *$ & $0.049 * * *$ & $0.066^{* * * *}$ & $0.092 * * *$ & $0.118^{* * *}$ & $0.105 * * *$ & $0.079 * * *$ \\
\hline & {$[6.53]$} & {$[3.22]$} & {$[9.76]$} & {$[10.92]$} & {$[8.90]$} & {$[2.42]$} & {$[4.30]$} & {$[3.96]$} & {$[7.39]$} & {$[8.08]$} & {$[7.57]$} & {$[7.58]$} & {$[4.50]$} & {$[2.76]$} \\
\hline \multirow[t]{2}{*}{ Revenue from fiscal equalization } & 0 & 0 & -0.002 & -0.001 & 0 & 0 & $0.001 *$ & $0.002^{* *}$ & $0.001^{* *}$ & 0.002 & $-0.003 * *$ & -0.001 & -0.001 & -0.002 \\
\hline & {$[0.19]$} & {$[0.05]$} & [1.59] & {$[0.77]$} & {$[0.07]$} & {$[0.53]$} & [1.74] & [2.29] & {$[2.06]$} & {$[0.83]$} & {$[2.47]$} & {$[0.55]$} & {$[0.35]$} & {$[0.42]$} \\
\hline \multirow[t]{2}{*}{ Community net wealth } & $0.031^{* * *}$ & 0.008 & $-0.015 * *$ & -0.004 & 0.001 & 0.001 & -0.004 & -0.007 & 0.004 & 0.002 & -0.007 & -0.012 & -0.025 & -0.046 \\
\hline & {$[2.59]$} & [1.01] & {$[2.07]$} & {$[0.45]$} & {$[0.19]$} & {$[0.11]$} & {$[0.90]$} & [1.39] & {$[0.64]$} & [0.29] & {$[0.64]$} & [0.94] & {$[1.25]$} & {$[1.53]$} \\
\hline \multirow[t]{2}{*}{ Highway access } & $-0.125^{* * *}$ & -0.022 & 0.01 & 0.025 & $0.050^{* *}$ & $0.035^{* *}$ & $0.035^{* *}$ & 0.022 & 0.004 & 0.001 & -0.043 & $-0.084 * *$ & -0.073 & -0.013 \\
\hline & {$[3.77]$} & {$[0.97]$} & [0.49] & [1.17] & [2.44] & {$[2.11]$} & {$[2.48]$} & {$[1.64]$} & {$[0.26]$} & {$[0.06]$} & [1.46] & {$[2.25]$} & {$[1.24]$} & {$[0.17]$} \\
\hline \multirow[t]{2}{*}{ Debt p.c. } & 0.144 & 0.083 & 0.077 & 0.033 & -0.02 & -0.042 & -0.046 & $-0.182 * * *$ & -0.01 & $-0.265 * * *$ & 0.049 & -0.103 & -0.239 & -0.272 \\
\hline & {$[0.94]$} & {$[0.99]$} & {$[0.78]$} & {$[0.35]$} & {$[0.25]$} & {$[0.63]$} & {$[0.84]$} & {$[2.66]$} & {$[0.14]$} & {$[3.31]$} & {$[0.39]$} & {$[0.73]$} & {$[0.97]$} & {$[0.79]$} \\
\hline \multirow[t]{2}{*}{ Constant } & $-3.965 * * *$ & $-3.067 * * *$ & $-2.742 * * *$ & $-2.557 * * *$ & $-3.092 * * *$ & $-2.486 * * *$ & $-2.242 * * *$ & $-2.366^{* * *}$ & $-2.568^{* * * *}$ & $-2.330^{* * * *}$ & $-2.013 * * *$ & -0.995 & -0.672 & -1.266 \\
\hline & {$[5.55]$} & {$[7.03]$} & {$[6.10]$} & {$[5.24]$} & {$[7.22]$} & {$[7.55]$} & {$[7.70]$} & {$[8.01]$} & {$[6.68]$} & {$[5.20]$} & {$[3.15]$} & {$[1.23]$} & {$[0.53]$} & {$[0.76]$} \\
\hline Observations & 684 & 684 & 684 & 684 & 684 & 684 & 684 & 684 & 684 & 684 & 683 & 684 & 680 & 681 \\
\hline Centered $R$-Squared & 0.2424 & 0.0925 & 0.3648 & 0.3064 & 0.1918 & 0.1859 & 0.2371 & 0.1852 & 0.2216 & 0.2468 & 0.0348 & 0.1199 & -0.0369 & 0.0113 \\
\hline
\end{tabular}


Table 2, Second stage Panel IV regression results, district fixed effects, 1991-2003, 171 communities, instrumented variables: tax multiplier and land price, parsimonious model

\begin{tabular}{|c|c|c|c|c|c|c|c|c|c|c|c|c|c|c|}
\hline Income Class, Swiss Francs p.a. & 0 & $0.0001-9999$ & $10-19.9999$ & 20-29.9999 & 30-39.9999 & 40-49.9999 & $50-59.9999$ & $60-69.9999$ & 70-79.9999 & 80-89.9999 & $90-99.9999$ & $100-149.9999$ & 150-199.9999 & $>200.000$ \\
\hline \multirow[t]{2}{*}{ Tax multiplier } & $0.023^{\star \star}$ & 0.006 & 0.007 & $0.014^{\star \star \star}$ & $0.015^{\star \star \star}$ & $0.006^{*}$ & -0.002 & -0.004 & $-0.008^{\star *}$ & $-0.014^{\star \star \star}$ & $-0.023^{\star \star \star}$ & $-0.031^{\star \star \star}$ & $-0.051^{\star \star \star}$ & $-0.046^{\star \star \star}$ \\
\hline & {$[2.17]$} & {$[1.60]$} & [1.48] & {$[2.72]$} & {$[3.91]$} & {$[1.81]$} & {$[0.66]$} & {$[1.37]$} & {$[2.08]$} & {$[2.89]$} & {$[3.59]$} & {$[3.95]$} & {$[4.55]$} & {$[3.38]$} \\
\hline \multirow[t]{2}{*}{ Land price } & $1.420^{\star \star \star}$ & 0.16 & -0.285 & -0.223 & -0.07 & -0.251 & $-0.415^{\star *}$ & -0.172 & -0.175 & -0.176 & -0.316 & -0.032 & -0.303 & 0.827 \\
\hline & {$[2.61]$} & {$[0.82]$} & {$[1.20]$} & {$[0.89]$} & {$[0.35]$} & {$[1.56]$} & {$[2.37]$} & {$[1.10]$} & {$[0.85]$} & {$[0.68]$} & {$[0.99]$} & {$[0.08]$} & {$[0.55]$} & [1.15] \\
\hline \multirow[t]{2}{*}{ Neighbor tax, district average } & 0 & $-0.002^{\star \star}$ & $-0.005^{\star \star \star}$ & $-0.006^{\star \star \star}$ & $-0.004^{\star \star \star}$ & $-0.001^{* *}$ & 0 & $0.002^{\star \star}$ & $0.002^{\star \star \star}$ & $0.004^{\star \star \star}$ & $0.006^{\star \star \star}$ & $0.012^{\star \star \star}$ & $0.012^{\star \star \star}$ & $0.015^{\star \star \star}$ \\
\hline & {$[0.07]$} & {$[2.24]$} & {$[4.65]$} & {$[5.81]$} & {$[4.75]$} & {$[1.99]$} & {$[0.46]$} & {$[2.54]$} & {$[2.59]$} & {$[3.23]$} & {$[4.22]$} & [6.22] & {$[3.96]$} & {$[4.52]$} \\
\hline \multirow[t]{2}{*}{ Airport noise } & $-0.129^{\star}$ & $-0.070^{\star \star}$ & $-0.061^{\star \star}$ & -0.044 & $0.046^{*}$ & $0.112^{\star * \star}$ & $0.103^{\star \star \star}$ & $0.098^{\star \star \star}$ & 0.048 & $0.066^{\star \star}$ & -0.002 & -0.045 & $-0.217^{\star \star \star}$ & $-0.352^{\star \star \star}$ \\
\hline & {$[1.88]$} & {$[2.47]$} & {$[2.13]$} & [1.41] & {$[1.65]$} & {$[5.25]$} & {$[4.86]$} & {$[5.67]$} & {$[1.64]$} & {$[2.30]$} & {$[0.04]$} & {$[0.90]$} & {$[2.84]$} & {$[4.04]$} \\
\hline \multirow[t]{2}{*}{ Share of foreigners } & -0.004 & $-0.004^{\star \star}$ & $0.003^{*}$ & $0.006^{\star \star \star}$ & $0.010^{\star \star \star}$ & $0.006^{\star \star \star}$ & $0.003^{\star \star}$ & $0.003^{\star \star \star}$ & 0 & $-0.006^{\star \star \star}$ & $-0.010^{\star \star \star}$ & $-0.016^{\star \star \star}$ & $-0.023^{\star \star \star *}$ & $-0.023^{\star \star \star}$ \\
\hline & {$[0.98]$} & {$[2.26]$} & {$[1.87]$} & {$[3.20]$} & {$[6.25]$} & {$[4.41]$} & {$[2.40]$} & {$[2.63]$} & {$[0.09]$} & {$[3.03]$} & {$[4.24]$} & {$[5.29]$} & {$[4.74]$} & {$[4.00]$} \\
\hline \multirow[t]{2}{*}{ Population } & $-0.006^{\star \star}$ & 0 & $0.003^{\star \star}$ & 0.002 & 0 & 0.001 & 0.001 & 0 & 0 & 0 & 0.001 & 0 & 0.002 & -0.002 \\
\hline & {$[2.01]$} & [0.12] & {$[2.36]$} & {$[1.53]$} & {$[0.40]$} & {$[1.08]$} & {$[1.56]$} & {$[0.54]$} & {$[0.10]$} & {$[0.22]$} & {$[0.47]$} & {$[0.28]$} & {$[0.61]$} & {$[0.59]$} \\
\hline \multirow[t]{2}{*}{ unemployment rate } & $0.164^{\star \star \star}$ & -0.011 & $-0.085^{\star \star \star}$ & $-0.082^{\star \star \star}$ & $-0.061^{\star \star \star}$ & $-0.019^{\star \star \star}$ & 0.008 & $0.015^{\star \star *}$ & $0.038^{\star \star \star}$ & $0.054^{\star \star \star}$ & $0.059^{\star \star \star}$ & $0.084^{\star * *}$ & $0.059^{\star \star \star}$ & $0.050^{*}$ \\
\hline & [7.95] & {$[1.36]$} & {$[9.13]$} & {$[8.92]$} & {$[8.13]$} & {$[2.98]$} & {$[1.20]$} & {$[2.63]$} & {$[4.94]$} & {$[5.68]$} & {$[4.98]$} & {$[5.64]$} & {$[2.66]$} & {$[1.92]$} \\
\hline \multirow[t]{2}{*}{ Constant } & $-6.573^{\star \star \star}$ & $-3.284^{\star \star \star}$ & $-2.488^{\star \star \star}$ & $-2.886^{\star \star \star}$ & $-3.157^{\star \star \star}$ & $-2.275^{\star \star \star}$ & $-1.697^{\star \star \star}$ & $-2.117^{\star \star \star}$ & $-2.043^{\star \star \star}$ & $-1.791^{\star \star}$ & -1.325 & -0.393 & 0.892 & -0.675 \\
\hline & {$[4.47]$} & {$[5.79]$} & {$[3.66]$} & [4.11] & {$[5.61]$} & {$[4.93]$} & {$[3.52]$} & {$[4.77]$} & {$[3.50]$} & {$[2.48]$} & [1.42] & {$[0.34]$} & {$[0.55]$} & {$[0.34]$} \\
\hline Observations & 684 & 684 & 684 & 684 & 684 & 684 & 684 & 684 & 684 & 684 & 683 & 684 & 680 & 681 \\
\hline Centered $R$-Squared & 0.2424 & 0.0925 & 0.3648 & 0.3064 & 0.1918 & 0.1859 & 0.2371 & 0.1852 & 0.2216 & 0.2468 & 0.0348 & 0.1199 & -0.0369 & 0.0113 \\
\hline & & & & & & & & & & & & & & \\
\hline
\end{tabular}


Table 3: Spatial error regressions for interjurisdictional income sorting among 14 income class shares, 2003, 171 communities

\begin{tabular}{|c|c|c|c|c|c|c|c|c|c|c|c|c|c|c|}
\hline Income Class, Swiss Francs p.a. & 0 & $0.0001-9999$ & $10-19.9999$ & $20-29.9999$ & 30-39.9999 & $40-49.9999$ & $50-59.9999$ & $60-69.9999$ & 70-79.9999 & $80-89.9999$ & $90-99.9999$ & $100-149.9999$ & 150-199.9999 & $>200.000$ \\
\hline \multirow[t]{2}{*}{ Tax multiplier } & 0.002 & 0.002 & $0.008^{* * *}$ & $0.010^{* * *}$ & $0.008^{* * *}$ & $0.006^{* * *}$ & $0.002 * *$ & -0.002 & $-0.003^{* *}$ & $-0.005 * * *$ & $-0.008^{* * *}$ & $-0.012^{* * * *}$ & $-0.017 * * *$ & $-0.021 * * *$ \\
\hline & {$[0.66]$} & [1.16] & {$[4.80]$} & {$[6.30]$} & {$[6.67]$} & {$[5.60]$} & {$[2.45]$} & [1.63] & {$[2.49]$} & {$[3.43]$} & {$[5.14]$} & {$[6.19]$} & {$[5.51]$} & [4.91] \\
\hline \multirow[t]{2}{*}{ Land price } & 0.18 & 0.019 & -0.034 & -0.011 & $-0.120^{* *}$ & $-0.111^{* *}$ & -0.063 & -0.08 & -0.092 & -0.047 & 0.011 & -0.004 & 0.07 & $0.360^{*}$ \\
\hline & [1.60] & {$[0.26]$} & {$[0.45]$} & {$[0.11]$} & {$[1.96]$} & {$[2.07]$} & {$[1.06]$} & [1.44] & [1.19] & [0.67] & {$[0.12]$} & {$[0.04]$} & [0.53] & {$[1.82]$} \\
\hline \multirow[t]{2}{*}{ Neighbor tax, district average } & 0.003 & -0.001 & 0.001 & 0.001 & 0.001 & -0.001 & -0.002 & 0.001 & -0.002 & -0.002 & -0.001 & -0.001 & -0.004 & 0.003 \\
\hline & [1.10] & {$[0.73]$} & {$[0.43]$} & {$[0.72]$} & {$[0.82]$} & {$[0.60]$} & [1.25] & {$[0.49]$} & {$[1.07]$} & [1.10] & [0.47] & {$[0.25]$} & [1.17] & [0.54] \\
\hline \multirow[t]{2}{*}{ Airport noise } & -0.077 & -0.078 & 0.041 & 0.046 & 0.049 & $0.094 * * *$ & $0.079^{* *}$ & $0.067^{*}$ & -0.001 & -0.061 & -0.062 & -0.102 & $-0.189^{*}$ & $-0.337 * * *$ \\
\hline & [0.99] & [1.13] & {$[0.92]$} & {$[0.98]$} & {$[1.18]$} & {$[3.08]$} & {$[2.19]$} & {$[1.87]$} & {$[0.03]$} & {$[1.42]$} & [1.08] & [1.62] & {$[1.87]$} & [3.38] \\
\hline \multirow[t]{2}{*}{ Lake Zurich } & -0.048 & 0.014 & $0.194 * *$ & 0.065 & $0.099^{*}$ & -0.029 & -0.096 & -0.05 & -0.096 & -0.027 & -0.138 & 0.056 & 0.179 & 0.063 \\
\hline & {$[0.45]$} & {$[0.17]$} & [1.97] & {$[1.09]$} & [1.65] & {$[0.50]$} & {$[1.54]$} & {$[0.97]$} & [1.47] & {$[0.31]$} & {$[1.48]$} & {$[0.60]$} & {$[1.38]$} & {$[0.32]$} \\
\hline \multirow[t]{2}{*}{ Lake Greifensee } & $0.008^{* *}$ & $0.007 * *$ & 0.002 & $0.007 * *$ & $0.005^{*}$ & 0.002 & 0 & -0.001 & -0.004 & -0.004 & $-0.007^{*}$ & $-0.011^{* *}$ & $-0.016 * * *$ & $-0.041^{* * *}$ \\
\hline & {$[2.21]$} & {$[2.00]$} & {$[0.56]$} & {$[2.33]$} & [1.90] & {$[0.83]$} & {$[0.00]$} & {$[0.55]$} & [1.38] & [1.24] & {$[1.80]$} & {$[2.46]$} & {$[2.61]$} & [3.29] \\
\hline \multirow[t]{2}{*}{ Sea level } & -0.024 & 0.039 & -0.107 & 0.019 & $-0.118^{*}$ & 0.02 & 0.06 & -0.031 & 0.085 & -0.005 & 0.138 & 0.017 & 0.022 & 0.199 \\
\hline & {$[0.20]$} & {$[0.42]$} & [1.13] & {$[0.28]$} & {$[1.80]$} & {$[0.31]$} & [0.99] & {$[0.62]$} & [1.25] & {$[0.06]$} & {$[1.46]$} & {$[0.18]$} & {$[0.16]$} & {$[0.88]$} \\
\hline \multirow[t]{2}{*}{ Train Station } & $0.001 * *$ & $0.000^{*}$ & $0.001 * * *$ & $0.000^{*}$ & 0 & $-0.000^{* *}$ & 0 & 0 & $-0.001 * * *$ & $-0.001 *$ & $-0.001 * * *$ & -0.001 & 0 & 0.001 \\
\hline & {$[2.56]$} & {$[1.76]$} & {$[4.16]$} & {$[1.76]$} & {$[0.35]$} & {$[2.44]$} & [1.37] & [1.39] & {$[2.75]$} & [1.87] & {$[3.40]$} & {$[1.52]$} & {$[0.53]$} & [1.33] \\
\hline \multirow[t]{2}{*}{ Highway access } & 0.018 & 0.037 & 0.01 & 0.044 & $0.045^{* *}$ & 0.026 & -0.014 & -0.008 & 0.018 & -0.01 & -0.055 & $-0.109 * * *$ & $-0.132^{* * *}$ & -0.143 \\
\hline & {$[0.36]$} & [0.94] & {$[0.28]$} & {$[1.39]$} & {$[2.07]$} & {$[1.03]$} & {$[0.62]$} & [0.33] & {$[0.60]$} & {$[0.28]$} & {$[1.32]$} & {$[2.60]$} & {$[2.14]$} & [1.64] \\
\hline \multirow[t]{2}{*}{ Share of elderly } & $-0.137 * * *$ & 0.028 & 0.04 & -0.002 & 0.04 & -0.004 & 0.011 & 0.008 & -0.008 & $0.081 * *$ & -0.055 & 0.031 & 0.009 & -0.055 \\
\hline & {$[3.02]$} & {$[0.61]$} & [1.14] & {$[0.05]$} & {$[1.38]$} & {$[0.16]$} & {$[0.48]$} & {$[0.33]$} & {$[0.29]$} & {$[2.18]$} & {$[1.32]$} & {$[0.64]$} & {$[0.11]$} & {$[0.47]$} \\
\hline \multirow[t]{2}{*}{ Share of young } & -0.835 & -1.049 & 1.168 & $1.814^{* *}$ & 0.454 & -0.423 & -0.122 & -0.554 & -0.333 & -1.2 & $-1.882^{* * *}$ & $-1.835^{*}$ & -1.506 & 4.427 \\
\hline & {$[0.79]$} & [1.00] & [1.41] & {$[2.13]$} & {$[0.72]$} & {$[0.62]$} & {$[0.18]$} & [0.96] & {$[0.43]$} & {$[1.15]$} & {$[1.98]$} & {$[1.74]$} & {$[0.90]$} & [1.10] \\
\hline \multirow[t]{2}{*}{ Net migration } & $-3.295^{*}$ & -0.04 & -0.301 & -1.751 & -0.392 & $-2.291^{* *}$ & -0.747 & 1.362 & 1.039 & 1.704 & 0.082 & 1.468 & 2.882 & 3.134 \\
\hline & {$[1.81]$} & {$[0.02]$} & {$[0.22]$} & [1.36] & {$[0.38]$} & {$[2.15]$} & {$[0.87]$} & {$[1.17]$} & {$[0.93]$} & {$[1.18]$} & {$[0.05]$} & [0.82] & [0.94] & {$[0.97]$} \\
\hline \multirow[t]{2}{*}{ Share of pupils. } & 0.163 & -0.948 & -1.222 & -1.088 & 1.209 & 0.313 & -0.225 & -0.379 & 0.125 & -1.031 & 0.705 & 1.178 & 0.669 & $7.478^{* *}$ \\
\hline & {$[0.11]$} & {$[0.70]$} & {$[0.98]$} & {$[0.96]$} & [1.59] & [0.41] & {$[0.33]$} & {$[0.50]$} & {$[0.13]$} & {$[0.76]$} & {$[0.57]$} & [0.94] & {$[0.43]$} & {$[2.53]$} \\
\hline \multirow[t]{2}{*}{ Contributions to public transport } & -2.279 & -6.466 & 3.437 & 2.76 & -1.819 & 5.586 & $8.078^{* *}$ & -1.595 & 3.312 & 4.076 & 4.299 & -7.502 & $-21.566^{* *}$ & 5.254 \\
\hline & {$[0.35]$} & [1.04] & {$[0.60]$} & {$[0.62]$} & {$[0.53]$} & [1.29] & {$[2.22]$} & {$[0.38]$} & {$[0.67]$} & {$[0.63]$} & [0.84] & [1.24] & {$[2.10]$} & [0.24] \\
\hline \multirow[t]{2}{*}{ Physicians p.c. } & -0.456 & -0.662 & -0.702 & $-1.522 * *$ & 0.005 & 0.198 & 0.108 & $-2.070 * * *$ & -0.554 & 1.066 & 0.974 & 0.945 & $3.818^{* * *}$ & 2.634 \\
\hline & {$[0.62]$} & {$[0.51]$} & {$[0.93]$} & {$[2.22]$} & {$[0.01]$} & [0.33] & {$[0.25]$} & {$[2.91]$} & {$[0.66]$} & {$[1.30]$} & {$[0.90]$} & {$[0.94]$} & {$[2.89]$} & [1.43] \\
\hline \multirow[t]{2}{*}{ Share of foreigners } & 9.984 & -6.703 & -24.666 & -10.73 & 5.533 & 9.616 & -2.031 & 4.788 & -13.596 & -9.628 & 17.583 & -16.121 & -8.258 & 45.055 \\
\hline & [0.34] & {$[0.28]$} & {$[1.16]$} & {$[0.64]$} & [0.34] & {$[0.59]$} & {$[0.16]$} & {$[0.31]$} & {$[0.84]$} & {$[0.52]$} & {$[0.71]$} & {$[0.58]$} & [0.21] & {$[0.83]$} \\
\hline \multirow[t]{2}{*}{ Right wing party share } & $0.011^{* *}$ & 0.006 & 0.001 & 0.003 & $0.006^{* *}$ & 0.002 & -0.001 & -0.001 & -0.001 & 0.001 & -0.004 & $-0.012 * *$ & -0.009 & -0.009 \\
\hline & [2.19] & {$[1.20]$} & {$[0.26]$} & {$[0.80]$} & {$[2.16]$} & {$[0.74]$} & {$[0.22]$} & {$[0.45]$} & {$[0.20]$} & {$[0.34]$} & {$[0.98]$} & {$[2.34]$} & {$[0.97]$} & [0.89] \\
\hline \multirow[t]{2}{*}{ Population } & -0.005 & -0.001 & 0 & $0.009 * * *$ & $0.010^{* * *}$ & $0.005^{* *}$ & 0 & -0.002 & -0.003 & $-0.008 * * *$ & $-0.007^{* *}$ & $-0.016 * * *$ & $-0.020^{* * *}$ & -0.002 \\
\hline & [1.57] & [0.16] & {$[0.05]$} & {$[4.20]$} & {$[5.10]$} & {$[2.27]$} & {$[0.26]$} & [1.04] & {$[1.37]$} & {$[2.65]$} & {$[2.45]$} & {$[5.56]$} & {$[3.82]$} & {$[0.16]$} \\
\hline Unemployment rate & 0 & 0 & $0.001 * *$ & 0.001 & 0 & 0 & 0 & 0 & 0 & $-0.001 * *$ & 0 & $-0.001 *$ & $-0.002 * * *$ & $-0.002 *$ \\
\hline & [0.04] & {$[0.05]$} & {$[2.19]$} & [1.40] & [0.53] & {$[0.21]$} & {$[1.02]$} & {$[0.56]$} & [0.25] & {$[2.06]$} & [0.42] & {$[1.71]$} & {$[2.61]$} & [1.81] \\
\hline Revenue from fiscal equalization & -0.055 & $-0.070 * *$ & -0.01 & -0.007 & 0.014 & 0.016 & $0.034 * *$ & 0.022 & -0.005 & -0.04 & -0.018 & -0.012 & -0.028 & -0.068 \\
\hline & [1.63] & {$[2.08]$} & [0.43] & {$[0.30]$} & {$[0.78]$} & {$[1.07]$} & {$[2.07]$} & [1.08] & {$[0.26]$} & [1.50] & [0.64] & {$[0.36]$} & [0.57] & {$[1.26]$} \\
\hline Community net wealth & 0 & $-0.000 * *$ & 0 & 0 & $-0.000 * *$ & 0 & $0.000^{* *}$ & $0.000^{* * *}$ & $0.000 * * *$ & 0 & 0 & 0 & 0 & 0 \\
\hline & [1.45] & {$[2.46]$} & [1.48] & {$[0.60]$} & {$[2.41]$} & {$[0.76]$} & {$[2.15]$} & {$[2.84]$} & {$[4.31]$} & [1.08] & [0.91] & {$[0.75]$} & {$[0.27]$} & [0.74] \\
\hline Debt p.c. & 0.002 & 0.009 & -0.009 & -0.006 & $-0.013^{*}$ & -0.007 & -0.005 & -0.007 & 0.001 & 0.009 & 0.006 & $0.014^{*}$ & $0.034^{* * *}$ & 0.011 \\
\hline & [0.17] & [1.09] & [1.11] & {$[0.93]$} & {$[1.96]$} & [1.33] & [1.15] & {$[1.32]$} & {$[0.16]$} & [1.32] & [0.74] & [1.75] & {$[2.60]$} & [0.54] \\
\hline Constant & 0.028 & -0.118 & 0.256 & 0.034 & -0.134 & -0.073 & -0.026 & 0.05 & -0.081 & $-0.291 * *$ & 0.003 & -0.021 & $-0.359^{*}$ & -0.184 \\
\hline & {$[0.16]$} & {$[0.83]$} & {$[1.60]$} & {$[0.31]$} & {$[1.10]$} & {$[0.72]$} & {$[0.31]$} & {$[0.54]$} & {$[0.70]$} & {$[2.23]$} & {$[0.02]$} & {$[0.16]$} & {$[1.86]$} & {$[0.50]$} \\
\hline Number of observations & 171 & 171 & 171 & 171 & 171 & 171 & 171 & 171 & 171 & 171 & 171 & 171 & 171 & 171 \\
\hline
\end{tabular}

$*$ significant at $10 \% ; * *$ significant at $5 \%$; $* *$ significant at $1 \%$; standard errors below coefficients 


\section{Appendix 1: The canton Zurich: 171 local communities in 12 districts}

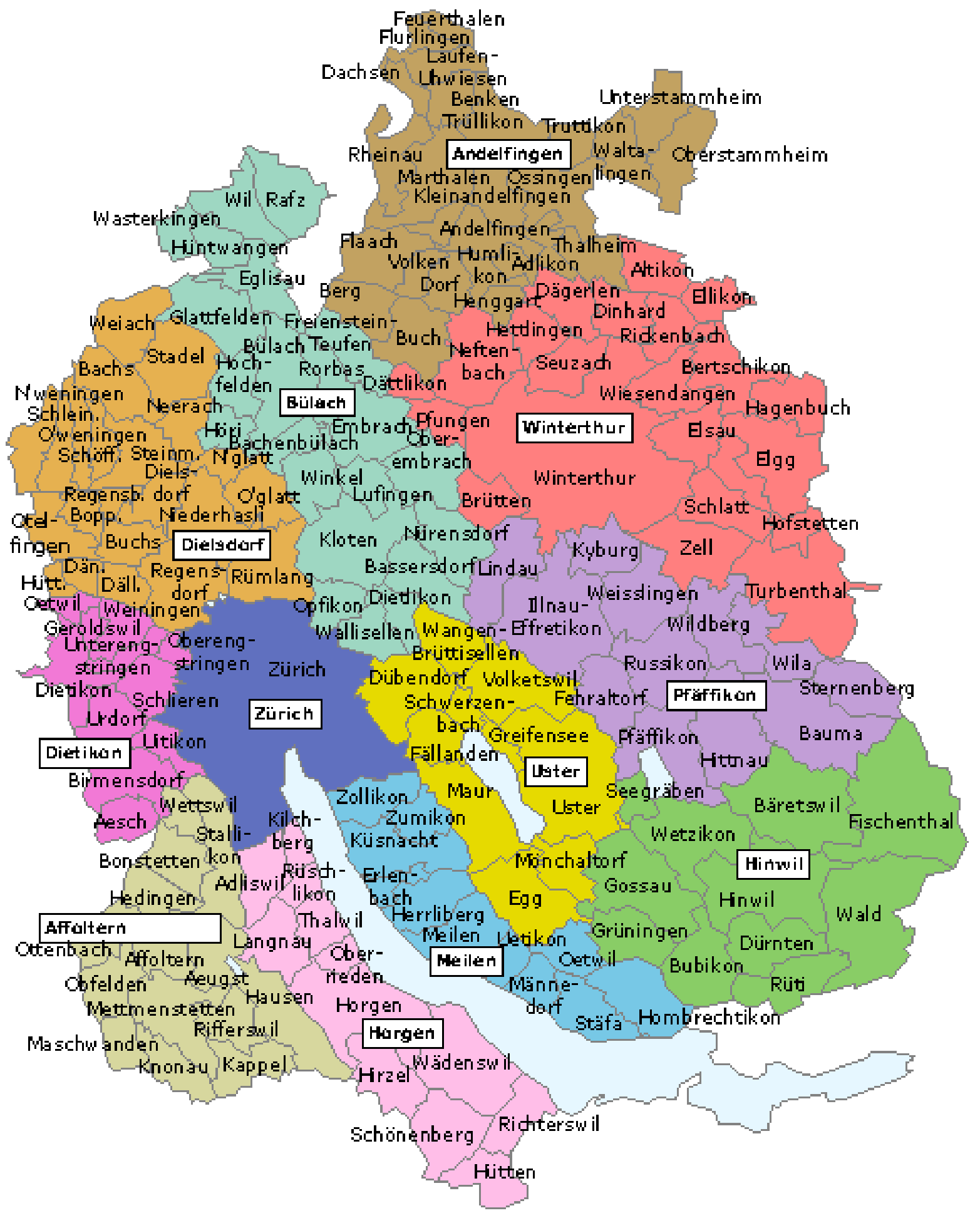


Appendix 1b: Progressiveness of the Tax Scheme in the Canton of Zurich, 2008. ${ }^{10}$

Tax rates for different income classes: state and localtax for the city of Zurich Dark: marginal tax rates for singles, Grey: marginal tax rates for families, Dashed: average tax rates

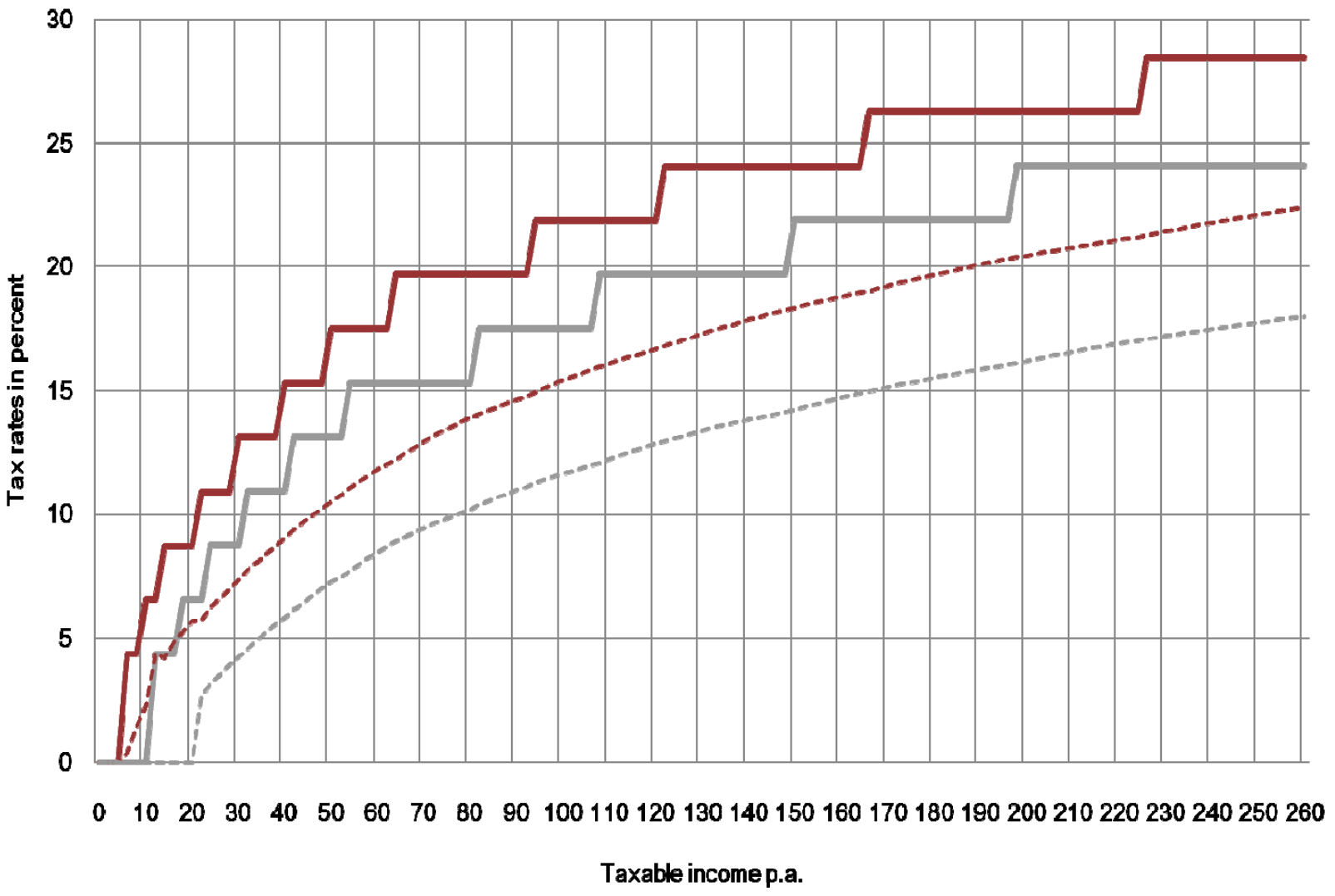

${ }^{10}$ Family is defined as a married couple with two children; family tariff includes tax allowance for two children. There is no married couples tax splitting in Switzerland. 
Appendix 2: Summary statistics

\begin{tabular}{|c|c|c|c|c|c|}
\hline & Obs & Mean & St. Dev. & Min. & Max. \\
\hline logoddsperccll & 676 & -2.940 & 0.411 & -4.808 & -1.735 \\
\hline logoddsperccl2 & 676 & -2.822 & 0.236 & -3.809 & -2.204 \\
\hline logoddsperccl3 & 676 & -2.571 & 0.276 & -3.248 & -1.634 \\
\hline logoddsperccl4 & 676 & -2.236 & 0.273 & -3.027 & -1.391 \\
\hline logoddsperccl5 & 676 & -1.927 & 0.242 & -2.859 & -1.361 \\
\hline logoddsperccl6 & 676 & -1.882 & 0.190 & -2.588 & -1.226 \\
\hline logoddsperccl7 & 676 & -2.089 & 0.167 & -2.637 & -1.663 \\
\hline logoddsperccl8 & 676 & -2.391 & 0.168 & -3.145 & -1.903 \\
\hline logoddsperccl9 & 676 & -2.722 & 0.210 & -3.847 & -2.130 \\
\hline logoddsperccl10 & 676 & -3.077 & 0.261 & -4.585 & -2.430 \\
\hline logoddsperccl11 & 676 & -3.422 & 0.330 & -5.144 & -2.602 \\
\hline logoddsperccl12 & 676 & -2.624 & 0.422 & -4.546 & -1.783 \\
\hline logoddsperccl13 & 676 & -3.983 & 0.622 & -6.117 & 0.000 \\
\hline logoddsperccl14 & 676 & -4.023 & 0.840 & -6.724 & 0.000 \\
\hline Tax multiplier & 676 & 113.797 & 13.375 & 69.000 & 131.000 \\
\hline Neighbor tax, district average & 676 & 112.865 & 9.094 & 86.000 & 130.000 \\
\hline Land Price & 676 & 613.648 & 248.660 & 148.000 & $3,272.000$ \\
\hline Lake Zurich & 676 & 0.101 & 0.301 & 0.000 & 1.000 \\
\hline Lake Greifensee & 676 & 0.041 & 0.199 & 0.000 & 1.000 \\
\hline Lake Pfäffiker See & 676 & 0.018 & 0.132 & 0.000 & 1.000 \\
\hline Airport noise & 676 & 0.107 & 0.309 & 0.000 & 1.000 \\
\hline Distance to Zurich & 676 & 17.709 & 7.644 & 0.000 & 36.000 \\
\hline Train Station & 676 & 0.515 & 0.500 & 0.000 & 1.000 \\
\hline Highway Access & 676 & 0.371 & 0.484 & 0.000 & 1.000 \\
\hline Sea level & 676 & 475.528 & 84.664 & 360.000 & 870.000 \\
\hline Share of elderly & 676 & 0.121 & 0.033 & 0.040 & 0.240 \\
\hline Share of young & 676 & 0.187 & 0.030 & 0.109 & 0.306 \\
\hline Net migration, perc. & 676 & 0.007 & 0.018 & -0.042 & 0.100 \\
\hline Share of pupils & 676 & 0.025 & 0.009 & 0.000 & 0.082 \\
\hline Contributions to public transport, p.c. & 676 & 0.026 & 0.027 & 0.001 & 0.207 \\
\hline Physicians p.c. & 676 & 0.001 & 0.001 & 0.000 & 0.004 \\
\hline Share of foreigners & 676 & 13.001 & 7.423 & 1.000 & 42.100 \\
\hline Share of right wing party & 676 & 37.424 & 11.226 & 12.300 & 71.500 \\
\hline Population & 676 & $7,063.240$ & $27,059.762$ & 251.000 & $350,815.000$ \\
\hline Unemployment rate & 676 & 1.919 & 1.357 & 0.000 & 7.500 \\
\hline Tax revenue & 676 & $18,185,068.000$ & $81,645,549.000$ & $277,189.600$ & $1,200,000,000.000$ \\
\hline Community income from tax equalization scheme & 676 & $1,332,793.800$ & $6,089,766.800$ & 0.000 & $124,000,000.000$ \\
\hline Community net wealth & 676 & $3,762.336$ & $2,407.643$ & 0.000 & $13,849.000$ \\
\hline Debt p.c. & 676 & 381.980 & 150.139 & -560.993 & $1,236.596$ \\
\hline Community net worth p.c. & 676 & $1,519.939$ & $3,291.217$ & $-14,599.000$ & $11,901.000$ \\
\hline
\end{tabular}




\section{Appendix 3: Data sources and Definitions}

\begin{tabular}{|c|c|c|}
\hline Variable & Description & Source \\
\hline Income shares & $\begin{array}{l}\text { Percentage share of taxpayers in an income class } \\
\text { (taxable income) }\end{array}$ & $\begin{array}{l}\text { Zürcher Staatssteuerstatistik } \\
\text { 1991, 1995, 1999, } 2003 .\end{array}$ \\
\hline Tax multiplier & $\begin{array}{l}\text { Tax multiplier determining local tax rates, } \\
\text { percentage of cantonal tax rate. }\end{array}$ & $\begin{array}{l}\text { Statistisches Amt des Kantons } \\
\text { Zürich (2008), }\end{array}$ \\
\hline Land price & Mean price per square meter in Swiss Francs & Statistisches Amt des Kantons \\
\hline Neighbor tax, district average & $\begin{array}{l}\text { Average of tax multipliers of all other communities } \\
\text { in a district }\end{array}$ & $\begin{array}{l}\text { Statistisches Amt des Kantons } \\
\text { Zürich (2008), }\end{array}$ \\
\hline Share of elderly & Share of inhabitants over age 65 & Statistisches Amt des Kantons \\
\hline Share of young & Share of inhabitants below age 15 & Statistisches Amt des Kantons \\
\hline Net migration & Net migration into a community & Statistisches Amt des Kantons \\
\hline Share of pupils & $\begin{array}{l}\text { Share of Pupils (Kindergarden, elementary school, } \\
\text { high school and vocational education) on total } \\
\text { population }\end{array}$ & $\begin{array}{l}\text { Statistisches Amt des Kantons } \\
\text { Zürich (2008) }\end{array}$ \\
\hline Payments to public transport & $\begin{array}{l}\text { Per capita spending to the local public transport } \\
\text { association ZVV (Zürcher Verkehrsverbund) }\end{array}$ & $\begin{array}{l}\text { Statistisches Amt des Kantons } \\
\text { Zürich (2008) }\end{array}$ \\
\hline Doctors p.c. & Share of medical doctors on total population & Statistisches Amt des Kantons \\
\hline Share of foreigners & Share of foreigners on total population & Bundesamt für Statistik \\
\hline Right wing party share & $\begin{array}{l}\text { Share of SVP (right wing party) voters in cantonal } \\
\text { parliamentary election }\end{array}$ & $\begin{array}{l}\text { Statistisches Amt des Kantons } \\
\text { Zürich, Ergebnisse }\end{array}$ \\
\hline Population & Absolute number of population & Statistisches Amt des Kantons \\
\hline Unemployment rate & Unemployment rate, percentage & Bundesamt für Statistik \\
\hline Tax revenue & Per capita tax revenue & Statistisches Amt des Kantons \\
\hline Payments from fiscal equalization & $\begin{array}{l}\text { Per capita payments from the canton to the local } \\
\text { communities according to the fiscal equalization } \\
\text { scheme }\end{array}$ & $\begin{array}{l}\text { Statistisches Amt des Kantons } \\
\text { Zürich (2008) }\end{array}$ \\
\hline Debt p.c. & Per capita debt & Statistisches Amt des Kantons \\
\hline Community net wealth & Per capita public net wealth on financial assets & Statistisches Amt des Kantons \\
\hline Lake Zurich & Dummy for location at lake Zurich & http://www.gis.zh.ch/gb4/blue \\
\hline Lake Greifensee & Dummy for location at lake Greifensee & http://www.gis.zh.ch/gb4/blue \\
\hline Airport noise & $\begin{array}{l}\text { Dummy for communities that need extra noise } \\
\text { protection on houses due to airport noise as } \\
\text { determined by the Zurich airport authority (unique) }\end{array}$ & $\begin{array}{l}\text { http://www.programm2010.ch/ } \\
\text { wissen/wissen_02.html, Noise } \\
\text { level ES II }\end{array}$ \\
\hline Distance to Zurich & Distance to the city of Zurich, linear distance & Own calculations \\
\hline Train station & Dummy for a train station in the community & http://www.zvv.ch \\
\hline
\end{tabular}




\section{CESifo Working Paper Series}

for full list see www.cesifo-group.org/wp

(address: Poschingerstr. 5, 81679 Munich, Germany, office@cesifo.de)

2761 Larry Karp, Sacrifice, Discounting and Climate Policy: Five Questions, August 2009

2762 Marianna Belloc and Samuel Bowles, International Trade, Factor Mobility and the Persistence of Cultural-Institutional Diversity, August 2009

2763 Charles Noussair and Fangfang Tan, Voting on Punishment Systems within a Heterogeneous Group, August 2009

2764 Birgit Bednar-Friedl and Karl Farmer, Internationally Coordinated Emission Permit Policies: An Option for Withdrawers from the Kyoto Protocol?, August 2009

2765 Pierre M. Picard and David E. Wildasin, Labor Market Pooling, Outsourcing and Labor Contracts, August 2009

2766 Stefan Voigt and Lorenz Blume, The Economic Effects of Federalism and Decentralization - A Cross-Country Assessment, August 2009

2767 David S. Jacks, Christopher M. Meissner and Dennis Novy, Trade Booms, Trade Busts, and Trade Costs, August 2009

2768 Mario Jametti and Thomas von Ungern-Sternberg, Hurricane Insurance in Florida, August 2009

2769 Alessandro Balestrino, Kind of Black: The Musicians' Labour Market in Italy, August 2009

2770 Yosr Abid Fourati and Cathal O’Donoghue, Eliciting Individual Preferences for Pension Reform, August 2009

2771 Christian Breuer and Chang Woon Nam, VAT on Intra-Community Trade and Bilateral Micro Revenue Clearing in the EU, August 2009

2772 Choudhry Tanveer Shehzad, Jakob De Haan and Bert Scholtens, Growth and Earnings Persistence in Banking Firms: A Dynamic Panel Investigation, August 2009

2773 Erdal Yalcin, Uncertain Productivity Growth and the Choice between FDI and Export, August 2009

2774 Klaus Abberger, Wolfgang Nierhaus and Shynar Shaikh, Findings of the Signal Approach for Financial Monitoring in Kazakhstan, September 2009

2775 Sascha O. Becker, Francesco Cinnirella and Ludger Woessmann, The Trade-off between Fertility and Education: Evidence from before the Demographic Transition, September 2009 
2776 Thomas Aronsson and Erkki Koskela, Optimal Income Taxation, Outsourcing and Policy Cooperation in a Dynamic Economy, September 2009

2777 Joel Slemrod, Old George Orwell Got it Backward: Some Thoughts on Behavioral Tax Economics, September 2009

2778 Cagri Seda Kumru and Athanasios C. Thanopoulos, Social Security Reform and Temptation, September 2009

2779 Alessandro Bucciol and Roel M. W. J. Beetsma, Inter- and Intra-generational Consequences of Pension Buffer Policy under Demographic, Financial and Economic Shocks, September 2009

2780 Eduardo Strube and Marcelo Resende, Complementarity of Innovation Policies in the Brazilian Industry: An Econometric Study, September 2009

2781 Henry Tulkens and Vincent van Steenberghe, "Mitigation, Adaptation, Suffering": In Search of the Right Mix in the Face of Climate Change, September 2009

2782 Maria L. Loureiro, Anna Sanz-de-Galdeano and Daniela Vuri, Smoking Habits: Like Father, Like Son, Like Mother, Like Daughter, September 2009

2783 Momi Dahan, Tehila Kogut and Moshe Shalem, Do Economic Policymakers Practice what they Preach? The Case of Pension Decisions, September 2009

2784 Eytan Sheshinski, Uncertain Longevity and Investment in Education, September 2009

2785 Nannette Lindenberg and Frank Westermann, How Strong is the Case for Dollarization in Costa Rica? A Note on the Business Cycle Comovements with the United States, September 2009

2786 Leif Danziger, Noncompliance and the Effects of the Minimum Wage on Hours and Welfare in Competitive Labor Markets, September 2009

2787 Gerlinde Fellner, Rupert Sausgruber and Christian Traxler, Testing Enforcement Strategies in the Field: Legal Threat, Moral Appeal and Social Information, September 2009

2788 Gabriel J. Felbermayr, Mario Larch and Wolfgang Lechthaler, Unemployment in an Interdependent World, September 2009

2789 Sebastian G. Kessing, Federalism and Accountability with Distorted Election Choices, September 2009

2790 Daniel Gros, Global Welfare Implications of Carbon Border Taxes, September 2009

2791 Louis N. Christofides, Michael Hoy and Ling Yang, The Gender Imbalance in Participation in Canadian Universities (1977-2005), September 2009

2792 Jan K. Brueckner and Robert W. Helsley, Sprawl and Blight, September 2009 
2793 Vidar Christiansen and Stephen Smith, Externality-correcting Taxes and Regulation, September 2009

2794 John Beirne, Guglielmo Maria Caporale, Marianne Schulze-Ghattas and Nicola Spagnolo, Global and Regional Spillovers in Emerging Stock Markets: A Multivariate GARCH-in-mean Analysis, September 2009

2795 Rüdiger Pethig and Frieder Kolleß, Asymmetric Capital-Tax Competition, Unemployment and Losses from Capital Market Integration, September 2009

2796 Ngo Van Long, Horst Raff and Frank Stähler, Innovation and Trade with Heterogeneous Firms, September 2009

2797 Margit Osterloh and Bruno S. Frey, Research Governance in Academia: Are there Alternatives to Academic Rankings?, September 2009

2798 Thiess Buettner and Clemens Fuest, The Role of the Corporate Income Tax as an Automatic Stabilizer, September 2009

2799 Annette Alstadsæter, Measuring the Consumption Value of Higher Education, September 2009

2800 Peter Friedrich, Chang Woon Nam and Janno Reiljan, Local Fiscal Equalization in Estonia: Is a Reform Necessary?, September 2009

2801 Evžen Kočenda and Jan Hanousek, State Ownership and Control in the Czech Republic, September 2009

2802 Michael Stimmelmayr, Wage Inequality in Germany: Disentangling Demand and Supply Effects, September 2009

2803 Biswa N. Bhattacharyay, Towards a Macroprudential Surveillance and Remedial Policy Formulation System for Monitoring Financial Crisis, September 2009

2804 Margarita Katsimi, Sarantis Kalyvitis and Thomas Moutos, "Unwarranted" Wage Changes and the Return on Capital, September 2009

2805 Christian Lessmann and Gunther Markwardt, Aid, Growth and Devolution, September 2009

2806 Bas Jacobs and Dirk Schindler, On the Desirability of Taxing Capital Income to Reduce Moral Hazard in Social Insurance, September 2009

2807 Hans Gersbach and Noemi Hummel, Climate Policy and Development, September 2009

2808 David E. Wildasin, Fiscal Competition for Imperfectly-Mobile Labor and Capital: A Comparative Dynamic Analysis, September 2009

2809 Johan Eyckmans and Cathrine Hagem, The European Union's Potential for Strategic Emissions Trading through Minimal Permit Sale Contracts, September 2009 
2810 Ruediger Bachmann and Christian Bayer, The Cross-section of Firms over the Business Cycle: New Facts and a DSGE Exploration, October 2009

2811 Slobodan Djajić and Michael S. Michael, Temporary Migration Policies and Welfare of the Host and Source Countries: A Game-Theoretic Approach, October 2009

2812 Devis Geron, Social Security Incidence under Uncertainty Assessing Italian Reforms, October 2009

2813 Max-Stephan Schulze and Nikolaus Wolf, Economic Nationalism and Economic Integration: The Austro-Hungarian Empire in the Late Nineteenth Century, October 2009

2814 Emilia Simeonova, Out of Sight, Out of Mind? The Impact of Natural Disasters on Pregnancy Outcomes, October 2009

2815 Dan Kovenock and Brian Roberson, Non-Partisan 'Get-Out-the-Vote' Efforts and Policy Outcomes, October 2009

2816 Sascha O. Becker, Erik Hornung and Ludger Woessmann, Catch Me If You Can: Education and Catch-up in the Industrial Revolution, October 2009

2817 Horst Raff and Nicolas Schmitt, Imports, Pass-Through, and the Structure of Retail Markets, October 2009

2818 Paul De Grauwe and Daniel Gros, A New Two-Pillar Strategy for the ECB, October 2009

2819 Guglielmo Maria Caporale, Thouraya Hadj Amor and Christophe Rault, International Financial Integration and Real Exchange Rate Long-Run Dynamics in Emerging Countries: Some Panel Evidence, October 2009

2820 Saša Žiković and Randall K. Filer, Hybrid Historical Simulation VaR and ES: Performance in Developed and Emerging Markets, October 2009

2821 Panu Poutvaara and Andreas Wagener, The Political Economy of Conscription, October 2009

2822 Steinar Holden and Åsa Rosén, Discrimination and Employment Protection, October 2009

2823 David G. Mayes, Banking Crisis Resolution Policy - Lessons from Recent Experience Which elements are needed for robust and efficient crisis resolution?, October 2009

2824 Christoph A. Schaltegger, Frank Somogyi and Jan-Egbert Sturm, Tax Competition and Income Sorting: Evidence from the Zurich Metropolitan Area, October 2009 